Portland State University

PDXScholar

Rewriting History: Using Reconciliation Processes to Revise Dominant Cultural Narratives and Assessing Cultural Readiness for Reconciliation

Flannery Mack

Portland State University

Follow this and additional works at: https://pdxscholar.library.pdx.edu/honorstheses

Let us know how access to this document benefits you.

Recommended Citation

Mack, Flannery, "Rewriting History: Using Reconciliation Processes to Revise Dominant Cultural Narratives and Assessing Cultural Readiness for Reconciliation" (2016). University Honors Theses. Paper 292. https://doi.org/10.15760/honors.282

This Thesis is brought to you for free and open access. It has been accepted for inclusion in University Honors Theses by an authorized administrator of PDXScholar. Please contact us if we can make this document more accessible: pdxscholar@pdx.edu. 


\title{
Rewriting History: Using Reconciliation Processes to Revise Dominant Cultural Narratives and Assessing Cultural Readiness for Reconciliation
}

\author{
by \\ Flannery Mack \\ An undergraduate honors thesis submitted in partial fulfillment of the \\ requirements for the degree of \\ Bachelor of Arts \\ in \\ University Honors \\ and \\ English
}

Thesis Adviser:

Dr. Amanda Smith Byron

Portland State University

2016 


\section{Abstract}

Truth and Reconciliation processes are key to rebuilding societies damaged by broad-based, government-sanctioned violence by revising dominant cultural narratives of the violence. In Indonesia, there has been no such process following the killings of between 500,000 and 2 million suspected communists and others in 1965-66. This paper is an exploration of conflict transformation theory, and of what form a truth and reconciliation process might take in Indonesia following 50 years of impunity. Using Joshua Oppenheimer's 2012 and 2014 documentaries The Act of Killing and The Look of Silence as primary reference points, I apply critical discourse analysis to look at how the dominant narrative of the killings is upheld and discursively constructed, and at what counter-narratives are emerging that could give rise to conflict transformation and reconciliation. I ultimately offer an assessment of the readiness to take on such a process, based on analysis of the films and other contextual materials, including journalism and official documents regarding the killings. 


\section{Acknowledgments}

I greatly appreciate the guidance of Dr. Amanda Smith Byron, without whose collaboration, encouragement, and thoughtful insight I could not have completed this project. Thanks also to the wonderful administrators and faculty in the Portland State University Honors College, in particular Professors Kathleen Merrow and Jennifer Ruth, who taught me what text is and how to read it, and who pushed the boundaries of my knowledge, opening my mind to a much more expansive and thrilling reality. Thanks to Joshua Oppenheimer for bringing this story of Indonesia in 1965 to the attention of the Indonesian people and of the international community. Thanks to my mother, whose assistance and long, late nights editing and talking on the phone with me have carried me through my college career. And finally, I extend my deepest gratitude to the 1965 survivors and Indonesian activists and journalists, for their courage and determination in seeking justice. 


\section{Table of Contents}

I. Abstract...................................................................

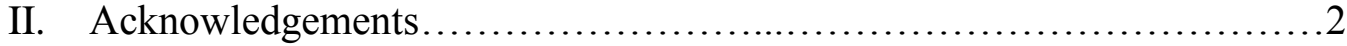

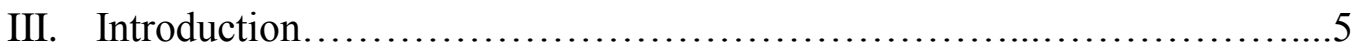

IV. Review of Primary and Secondary Source Materials.....................8

1. Secondary Source Materials............................................ 8

a. Theory of Truth and Reconciliation Processes: Conflict

Transformation.............................................. 8

b. The Role of Dialogue........................................11

c. Memory and Memorialization as Precursors or Companions to Reconciliation....................................................14

d. Apology and Forgiveness as Process...............................18

e. Reconciliation as Process...........................................20

f. The Problem of Impunity .....................................23

g. Discourse Analysis in Understanding Truth and Reconciliation...27

2. Primary Source Materials..............................................29

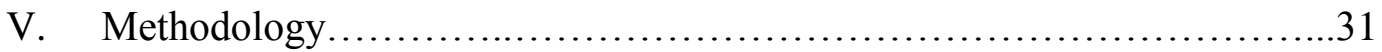

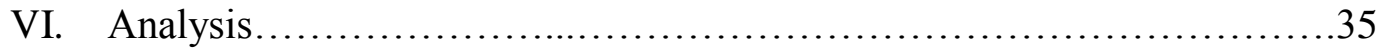

1. Joshua Oppenheimer's The Act of Killing and The Look of Silence........36

a. Discourse Analysis of The Act of Killing............................37

b. Discourse Analysis of The Look of Silence ..........................44

2. Indications of Indonesia's Readiness for a Truth and Reconciliation

Process from Primary Source Materials................................52 
a. Conflict Transformation.................................52

b. Dialogue..................................................57

c. Memory and Memorialization............................60

d. Apology and Forgiveness...............................63

e. Reconciliation.........................................67

VII. Conclusion....................................................69

VIII. Appendices................................................. 72

Appendix A: Wodak and Reisigl's Original Outline for the Discourse-

Historical Approach to Discourse Analysis...................... 72

Appendix B: Critical Discourse Analysis Chart for The Act of

Killing................................................ 75

Appendix C: Critical Discourse Analysis Chart for The Look of

Silence ...................................................... 78

IX. Works Cited........................................................ 81 


\section{Introduction}

In 2009, I spent a year living in Jakarta, Indonesia, as a high school foreign exchange student. Host families, teachers, and classmates embraced and supported me in an unforgettable way. I fell in love with this wonderful country and have since strived to learn as much as I can about Indonesia and its history. When Joshua Oppenheimer's 2012 and 2014 documentaries The Act of Killing and The Look of Silence were screened in theaters in my hometown, I rushed to see them. These films document massacres of civilians in 1965 after the Indonesian government was overthrown by the military. Early in the morning on September 30th, a group of "disaffected military officers" kidnapped and assassinated six of the most senior army generals and attempted a coup, which failed (McGregor). General Suharto crushed the coup and controlled the ensuing narrative, placing blame for the plot on the Indonesian Communist Party (Partai Komunis Indonesia- PKI) (McGregor). The army directed killings of PKI members and other affiliated organizations, such as the Indonesian Women's Movement. (McGregor). Anyone opposed to the military dictatorship or suspected to be sympathetic to the PKI could be accused of being a communist. This included union members, landless farmers, ethnic Chinese, left-leaning political activists, and intellectuals (Killing; Cribb and Ford; McGregor). At the local level, Suharto's orders to purge communists became a license to work out "old political, religious, and ethnic hatreds" (Parry 106). Astonishingly, hundreds of thousands were tortured and executed without weapons of war, by hand (106). In less than a year, between five hundred thousand and two million 'communists' were killed (Killing; Kwok, "Memory of Savage Anticommunist Killings"; McGregor). 
After the massacres, General Suharto continued to lead the country for 32 years, until 1998. In some cases, the architects and perpetrators of the slaughter still hold positions of power throughout the country, and are widely regarded as heroes given credit for shaping Indonesia's democracy (Killing). How can there possibly be a healthy community, much less a democracy, in this situation, where killers triumph and retain power for decades? The victorious murderers have subverted the truth to perpetuate the myth of their heroism in the dominant narrative of Indonesia's national identity.

The Act of Killing focuses on the perpetrators of the killings, The Look of Silence on the victims. I had only heard briefly about these events during my time as an exchange student. Comments made in passing, such as that communism was illegal in Indonesia, constituted the glimpses I had of this turbulent chapter of Indonesian history. I was shocked by the films, their portrayal of the culture of impunity for those who perpetrated the violence, and the ongoing threats, intimidation, and violence against survivors that still grip the country.

I am interested in processes that shape and define national narratives. The national narrative of Indonesia is reaching an exceptionally fascinating juncture, in which counternarratives surrounding the massacres of 1965-66 are newly developing both within Indonesia and on a global scale. The fifty-year anniversary of the massacres in October 2015, marked the following month by the convening of an International People's Tribunal for Indonesia in the Hague, placed the question of initiating a truth and reconciliation process center-stage. Oppenheimer's films explore what happens when government actors and their civilian confederates enjoy impunity after widespread executions of hundreds of thousands of civilians. The films are a compelling starting 
point for an analysis of fledgling counter-narratives as well as of the dominant narrative memorializing the events of 1965-66. The Indonesian government has not officially recognized these events as crimes. Though many of the people directly involved in the massacres as executioners and survivors are still living, the window in which a truth and reconciliation process involving them can take place is closing. Through this paper, I draw on conceptual frameworks from the fields of conflict resolution, using critical discourse analysis to examine the narratives of the killings presented by Oppenheimer's films for indications of readiness to change the dominant national narrative, and to initiate a truth and reconciliation process in Indonesia. 


\section{Review of Primary and Secondary Source Materials}

\section{Secondary Source Materials}

\section{a. Theory of Truth and Reconciliation Processes: Conflict Transformation}

Truth and reconciliation processes have been conceived and executed in numerous countries in response to episodes of unconstrained violence on a massive scale. Processes in South Africa following the collapse of the apartheid regime and in Rwanda in the wake of the genocide in 1994 are well known. Aspects of a truth and reconciliation process were also instrumental in Germany after World War II and in Northern Ireland after the peace accords. Guatemala undertook a Recovery of Historical Memory Project to address the legacy of its decades-long civil war (Maddison 217). Truth and reconciliation processes are complicated and varied projects. At the basis of any truth and reconciliation process lies the question of which goals should be pursued, through which particular institutional mechanisms, and in what order (Ciorciari and Ramji-Nogales 194). In the realm of conflict management and reparation after large-scale violence, these processes are key to finding a way to confront the past and find healing and progress. Objectives such as 'peace,' 'justice,' 'healing,' and 'democracy' drive these efforts (Maddison 40).

Defining the province, methodology, and achievable objectives of truth and reconciliation processes is a complex endeavor. Truth and reconciliation commissions (TRCs) are not tools for addressing routine crimes, even when many victims are involved. They are instead mechanisms used by governments to address wide-scale, illegal violence committed, supported, enabled, or tolerated by governments. They are also used to reunite societies after civil wars in which government forces have massacred 
civilians. As government apparatuses, TRCs bring legitimacy, power, access to information, the means of designing and building memorials, influence with all components of society, adequate funding, and the high profile required to change a national narrative (Brahm).

In popular culture, TRCs are understood to be linear constructs in which events unfold sequentially, beginning with fact-finding missions and ending with full societal reconciliation. People know TRCs to be governmentally-created entities which have a mandate to dismantle ahistorical national narratives by creating public fora in which events of the past can be grappled with and new understandings can be reached to make more positive relationships between the victims and perpetrators of violence possible (Ciorciari and Ramji-Nogales 196). Victims are acknowledged and given a platform to voice their grief and frustration. Perpetrators admit and explain wrongdoing and take responsibility. A breach in the culture is thus healed, and the community can move forward in peace and greater mutual understanding. To some extent, theorists accept this popular conception as a workable definition. David K. Androff, introducing a discussion of social work as a component of successful TRCs, defines TRCs as "a primary human rights intervention for post-conflict reconstruction" (Androff 1960). He sees TRCs as offering societies severely damaged by state-sanctioned violence a means to recovery which is in some cases superior to merely "maintaining security, providing humanitarian relief, promoting development, and seeking justice" (1961). In his view, TRCs provide restorative justice by investigating past abuses, hearing the stories of victims and perpetrators, and thus repairing the damaged social fabric (1960). 
Most scholars recognize a much more problematized theoretical framework for truth and reconciliation processes. Some would likely dispense with the term "TRC" due to its suggestion that a commission can accomplish repair and healing by conducting a fact-finding investigation and holding hearings. Theorists such as Sarah Maddison think of conflict characterized by violence on a massive scale - the kind of conflict which necessitates truth and reconciliation processes - in terms of conflict transformation rather than conflict resolution. Maddison disputes the theory of a cycle of conflict in which latent social tensions find public expression, escalate, then deescalate and resolve with post-conflict reconciliation (Maddison 23). This theory is fictitious in that it posits an end to conflict and conceives truth and reconciliation processes as the means to reaching that end. Maddison adopts the term "deeply divided societies" to describe communities "emerging from periods of violence and civil war, or that have other significant cleavages resulting from historical violence" (23). Maddison is cautious in her expectations from truth and reconciliation processes as a response to such violence in that "the violent conflict, repression, and injustice that make up the history of such societies are multilayered and multifaceted, making it virtually impossible to determine which wrongs can feasibly be addressed, what this process might entail, and how to prioritize such efforts" (23).

Conflict cannot be resolved by a truth and reconciliation process. Conflict is a complex social phenomenon that is essential in shaping healthy democratic societies (Maddison 23). Because of the persistent nature of conflict, reconciliation attempts do not begin with a "blank slate," but unfold in a context "laden with problematic historical events that remain alive in contemporary consciousness and demand attention and 
recognition" (Little; Lederach, as qtd. in Maddison 57). In fact, the long-term consequences of conflict are perpetual. The time never comes when "historical events or practices have run their course and no longer influence evolving social and practical relations" (Little, as qtd. in Maddison 58). The perpetuity of conflicts means that "they are constantly being reiterated, renegotiated and reconstituted and thus their impact on social and political structures is continual" (58). The "complex temporality" of conflict is thus a crucial consideration in conflict transformation efforts (58).

Conflict should be contained, channeled, and made overt through social and political processes that replace, and hopefully preclude, unconstrained violence. A process that replaces a nonfactual official narrative with an oversimplified narrative based on binaries of right and wrong, violated and violators, should be avoided (Maddison 25). The truth about conflicts can rarely be so cleanly divided. Direct violence may disappear temporarily or permanently, but structural and cultural violence arising from the deep fault lines that produced the historical breach persist and continue to produce marginalization, repression, and discrimination (Nadler, as qtd. in Maddison 27; McGregor). Failure to successfully transform the conflict leaves open the possibility of future episodes of unconstrained violence (27). Thus, the process must begin with a correct understanding of the nature of conflict and with the objective of conflict transformation. Maddison identifies the following elements, which must be interwoven in designing a truth and reconciliation process.

\section{b. The Role of Dialogue}

All theorists emphasize the crucial role dialogue plays in any reconciliation attempt. Dialogue, while seemingly simple, is a delicate procedure, and one that must be 
structured and guided towards constructive expression (Maddison 252). Emotions that have been repressed must be allowed to be fully expressed and realized. Dialogue is productive when managed in such a way that it can facilitate healing and be a starting point for change, not just an airing of grievances and a further cause for contention. The overarching goal of conflict transformation requires first a transformation in the way people in deeply divided societies talk to each other (255).

Most importantly, dialogue must lead to "public policies and concrete actions which can be measured" (Noriega, as qtd. in Maddison 267). The fact that it often does not has led to perceptions that dialogue is an unproductive or unnecessary procedure, one that succeeds in stirring up deep emotions while failing to realize its promises of change. Committed parties from various sectors of civil society must be actively involved to help balance and shape this outcome (267).“[M]eaningful conflict transformation” is dependent on collaboration among individuals, government departments, and communities committed to "patience, persistence, creativity, risk, tolerance, and substantial investment over a long period of time" (269).

John D. Ciorciari and Jaya Ramji-Nogales illustrate an additional feature of effective dialogue, which is that it must include diverse voices. They describe a process carried out in Cambodia by the governmental organization Renakse (Salvation Front), which conducted a nationwide review and condemnation of Khmer Rouge crimes (Ciorciari and Ramji-Nogales 200). The organizing committee held a series of community meetings at which victims gave testimonies about the brutality they faced and witnessed (200). Renakse unearthed mass graves and examined documents to collect evidence of damage done to both people and property by the Khmer Rouge (200). 
Victims were invited to sign petitions detailing these atrocities (200). Although this process appeared to be truth commission-like in its methods (that is, gathering information to present a different version of the truth, inviting victims to speak, and bringing perpetrators to justice), the Renakse process was ineffective because it did not include any Khmer Rouge voices (201). Due to this exclusion, no "genuine dialogue" took place "between former foes" (214). The community meetings "did little to encourage public apologies that could have facilitated healing" (214), and as a result, victims and perpetrators had no opportunity to humanize one another (201).

Another defect in the dialogue fostered by Renakse was that the findings were not shared with a broad audience (Ciorciari and Ramji-Nogales 201). Structured dialogues put on by the Extraordinary Chambers in the Courts of Cambodia (ECCC), a hybrid tribunal combining domestic and international laws, procedures, and personnel (205-6) at the community level provided greater public awareness of information and fostered conversation about Khmer Rouge atrocities (206, 214). Perhaps most importantly, the ECCC-sponsored dialogues "created a space for victims and perpetrators to interact, and fostered understanding and forgiveness" (214).

In order to successfully anticipate further processes, one purpose of dialogue must be to explore the "preferences of those who need to be reconciled" (Ciorciari and RamjiNogales 216) in regard to the truth and reconciliation process as a whole. The role of civil society is to "build neutral, non-political forums for truth telling involving genuine dialogue between survivors and perpetrators" (216). Well-structured dialogue "can humanize complex historical conflicts and enable former adversaries to engage positively 
with one another" (216). Through dialogue, a shared understanding of the events of the past, the responsible parties, and the victims may be achievable.

\section{c. Memory and Memorialization as Precursors or Companions to Reconciliation}

Another important precursor to reconciliation is an agreement on a shared account of history and a new approach to how the original violence will be remembered. As complex as truth and reconciliation processes are to design and execute, they are a crucial means of challenging ahistorical national narratives regarding violent social breaches on a massive scale. It is not enough to forget the past and move forward. The obscured past atrocity "will continue to constrain all efforts to construct a more democratic society until the nation develops an understanding of how [the victims of violence] experienced and internalized state and insurgent structures of terror as part of their individual and collective identities" (Sanford, as qtd. in Maddison 29). Even after decades, the experience of genocide persists in the national psyche as "an officially silenced national trauma reverberating throughout the society" (29).

Truth recognition processes, such as the Recovery of Historical Memory Project in Guatemala, are a crucial first step in confronting atrocities that have been officially denied or mischaracterized. "Establishing a shared truth about past collective violence and human rights abuses is seen as a 'prerequisite for achieving accountability, meaningful reconciliation, and a foundation for a common future"" (Chapman, as qtd. in Maddison 49). Acknowledgement of "huge violations of people's human rights" must precede reconciliation and conflict transformation efforts (Hunt, as qtd. in Maddison 44). The process of developing a shared narrative, of listening to others state their understandings of the past, and creating an account of a "chaotic and painful past" (161) 
is an important first step in reconciliation efforts, and lays the groundwork for greater efforts to manage conflict and begin healing. Some theorists caution that a universally shared understanding of the meaning of the facts may never be achieved. Fortunately, "A shared moral account of the nature of past wrongs" is not an indispensable prerequisite to moving forward (Schaap, as qtd. in Maddison 51).

The challenge of finding a shared national narrative about atrocities is particularly daunting in circumstances like Indonesia's, where a truth and reconciliation process is emerging in a context of impunity. While reconciling people is certainly the ultimate goal, it is not always the best place to start (Opotow 161). Opotow proposes first addressing "the contingencies of justice"-what happened in the past, who is responsible, and why these events happened in the first place (161-2). A single interpretation of the past is not expected to be agreed upon, but parties do need to be "mutually tolerant of a limited set of interpretations $[\ldots]$ a shared narrative may, therefore, require revising their preexisting narratives or reinterpreting their earlier experiences" (161).

The question of how high the level of agreement on the facts and their meaning has to be in order to ultimately succeed in conflict transformation is a perplexing one. Clearly, the dominant national narrative cannot continue to be rankly nonfactual. Factual accounts cannot continue to be faltering acts of narrative insurgency. The absence of a shared understanding of the past violence and its causes "reinforces the sense of isolation and difference between the two communities, underscoring the persistent threat of violence and impeding other reconciliation efforts" (McCaughey; Community Relations Council, as qtd. in Maddison 210). The critical mass of narrative agreement is 
particularized to a given society, but if it is not achieved, neither will conflict transformation be achieved (210).

In post-conflict societies, the dominant narrative is usually under the control of elites. For some theorists, the goal of TRCs is to replace the dominant narrative, which serves the purposes of elites and protects their power and privileges, with a narrative reflecting the lives of marginalized populations (Maddison 208). Such counter-narratives "refuse to allow past injustice to be excused as incidental to the nation-building agenda" (208). Little posits a far less ambitious goal when he says, “...reconciliation efforts should not focus so much on the discovery of one 'truth' but on how accommodation between conflicting historical accounts might be attained in order to 'make a conflict more liveable"” (Little, as qtd. in Maddison 210).

A companion effort to the retrieval of the facts and fashioning of a narrative is the memorialization of the story that emerges. Memorialization arises from memory, but also reaches back to reinforce the narrative that produces it. Murals and memorials in Guatemala, for example, ““[do] vital memorializing work' to help 'create a public, shared, and fixed rendering of the mass experience of violence"' (Nelson, as qtd. in Maddison 245). A larger scale museum memorializing the victims from both sides of the Guatemalan civil war is being constructed in a building that formerly housed the secret police archives (246). In addition to presenting information about historical genocides and other Latin American Cold War counterinsurgency wars, this museum will provide a "shrine space" to mourn the victims and casualties of the war, many of whom do not have a grave that can be visited on Dia de los Muertos (246). Julio Solórzano-Foppa, one of the architects of this project, finds it fitting "to carry on the tradition of building 
memorials 'in places where violations of human rights occurred"' (Solórzano-Foppa, as qtd. in Maddison 246). Such repurposing of public space for memorialization of the ascendant narrative seems best suited to societies in which there is a high level of agreement about the facts and their meaning.

Where widespread resistance to a new national narrative regarding atrocities may exist, more inclusive memorials may have a better chance of being successfully embedded in the consciousness of the community. For example, in Cambodia, stupas"Buddhist religious monuments used for worship and remembrance" (Ciorciari and Ramji-Nogales 201) — have been constructed where surviving family members can pray for the spirits of the dead. Possibly due to the sheer numbers of perpetrators, the Cambodian experience of successful memorialization has been with less divisive projects. "Ceremonies and memorials have been more conducive to healing when they have focused on sharing communal suffering and honoring loved ones rather than focusing enmity on perpetrators and their kin" (215).

Another consideration in memorialization is the local community. It is "at the local level that most people experience conflict," and the local level is where "the chances of reconciliation are greatest, because people know both each other and the issues at hand" (Wessels, as qtd. in Maddison 248). Impactful memorializations in Cambodia have been created in communities and have drawn on local culture and religion, "appealing to Buddhist principles of tolerance and forgiveness" (Ciorciari and Ramji-Nogales 215). Similarly, in a project called 'Re-Imagining Communities,' the Arts Council of Northern Ireland has replaced hundreds of murals delineating neighborhoods with threatening military-type imagery with images that convey a more accessible 
identity, such as football players or figures from Celtic mythology (Maddison 246). In one neighborhood, a painting of an armed partisan over the words 'YOU ARE NOW ENTERING LOYALIST SANDY ROW HEARTLAND OF SOUTH BELFAST ULSTER FREEDOM FIGHTERS', was covered up by a painting of King William III, the Prince of Orange (Maddison 246, original emphasis). The new image "still clearly marked the area as staunchly Protestant and loyalist, but the image itself was far less threatening" (246).

\section{d. Apology and Forgiveness as Process}

"Apologies are not simply an act but a process focused on the possibility of a future relationship" (Verdeja, as qtd. in Maddison 226). The symbolic power of acts of contrition and forgiveness, juxtaposing perpetrator and victim, can reverberate through a society, creating the possibility of reconciliation and shoring up a newly-adopted national narrative regarding officially-sanctioned atrocities (227-8). But how are apologies to be secured, and forgiveness to be given? After taking the newly-established narrative and numerous context-specific variables into account, the designers of the process must consider what is achievable as well as specifics such as who apologizes, who officiates, and who forgives. Since the violence was officially sanctioned, the perpetrators in most cases will not have been held accountable through criminal justice processes. The underlying conflict will have persisted as structural violence and oppression of victims even after the cessation of overt violence. If the perpetrators are willing to take responsibility and apologize completely for the wrongs they have committed, are victims expected to forgive them immediately and without reservation? The complexity of 
securing both apology and forgiveness in the face of ongoing oppression and impunity quickly becomes obvious.

Where achievable, apology and forgiveness are the desired next step after truth processes have successfully revised the official narrative of government-sanctioned atrocities. "Central to the relational tasks of reconciliation efforts are the projects designed to draw former enemies into relationship with one another through apology, forgiveness and individual and societal healing" (Maddison 225). Apologies are a deeply symbolic way to express responsibility and remorse (225). The same official actors who directly (or through predecessors) approved or ignored the killings are in a position to offer some means of making amends to victims. Removing barriers to opportunity, returning stolen property, and payment of reparations come to mind. Where apologies are not accompanied by "“direct and immediate actions"” or another sort of " "practical component," such as compensation, "they may amount to little more than a "hollow symbolic statement' that does little to transform the status of victims and survivors" (Minow, as qtd. in Maddison 227).

In a truth and reconciliation context, an apology is not only a statement, but also an action (Onus, qtd. in Maddison 227). "It's not enough to just say sorry. You've got to then take steps and follow it through" (227). Apologies serve to open "political space" in which "citizens may reflect on more critical views of their troubled histories" (226). This is especially evident in the case of apologies issued by political elites. The actions that result from these apologies have a particular importance as a response to countering entrenched social issues (225). Elite apologies can be a first step to instilling greater political stability (Verdeja, as qtd. in Maddison 225-6). The action they suggest is that 
"critical reinterpretations of history" are necessary, that victims are morally valuable and politically recognized, and that the public has the power to imagine new possibilities of relation between the state and society (225-6).

As to the question of how forgiveness is to be extracted from fantastically aggrieved victims, many suffering ongoing systemic abuse, Desmond Tutu cautions that people who have been victimized need not condone what has been done to them or to their family members, friends, or community. Once the wrong is taken seriously, that can "[draw] out the sting in the memory that threatens to poison our entire existence" (Tutu, as qtd. in Maddison 227). Forgiveness can justifiably be positioned as an expression and acts performed for the sake of victims themselves as well as for perpetrators and the culture as a whole. Forgiveness is a part of the healing process for survivors as well as for the larger community. "“[T]he healing of memories allows traumatized people to connect at 'the deepest human level', which [...] is important for national reconciliation" (Lapsley, qtd. in Maddison 229). While perfect apologies and unstinting forgiveness may prove elusive, they are still foundational elements of the process. However, in the absence of conflict transformation that results in what may reasonably be called reconciliation, the transference of the conflict into the political sphere will do. "[H]ealing processes can be understood as an attempt to negotiate the public emotional life of a divided society, placing anger and fear in context and drawing on other emotions, such as empathy and compassion, in the hope of establishing a more respectful relationship across difference and division" (230).

\section{e. Reconciliation as Process}


Recovering systematically repressed facts about the violent insult to the community, followed by apology and forgiveness to the extent those are achievable, opens a door to reconciliation (Maddison 48). Again, reconciliation here is not to be understood as a resolution of, and end to, conflict. Instead, reconciliation processes address "the political challenges involved in finding ways for people in deeply divided societies to live together democratically and non-violently, with radical differences" ( Ramsbotham et al., as qtd. in Maddison 45, original emphasis).

The term "reconciliation" is complicated and adaptable. Hamber and Kelly, for example, see reconciliation as composed of five elements: "the development of a shared vision of an interdependent and fair society; a means of acknowledging and dealing with the past; the building of positive relationships; significant cultural and attitudinal change; and substantial social, economic, and political change" (Hamber and Kelly, as qtd. in Maddison 49-50). What is reconciled in a reconciliation process is not the conflict within a deeply divided society, but past and present, the needs of the entire community and the needs of victims:

Reconciliation seeks to anticipate the future while acknowledging and memorializing the past; it seeks to be politically inclusive while focusing on the needs and rights of victims (du Toit 2009: 256); it is both discursive and normative (Renner 2012: 55); and 'at once political, legal, cultural, moral, psychological, and spiritual' (Kiss 2000: 80); it incorporates 'psychological, structural and political elements' (Wale 2013: 8); it is concerned with both institutional transformation and the restoration of trust (Mack 2011: 450-1); and it operates at multiple levels, including the 
personal and the political (Quinn 2009: 4). Reconciliation is emphatically not a process of conflict resolution of the kind that delegitimizes or represses important forms of political resistance and struggle (Schirch, as qtd. in Maddison 50-1).

"Despite its complexities," there is great value in preserving "the rhetorical power" of the concept of reconciliation, while simultaneously expanding its use to incorporate "aspects of transition, peacebuilding and transformation" (Maddison 40). Reconciliation plays a crucial role in "constituting a space for democratic politics out of a condition of violence" (Muldoon, as qtd. in Maddison 40). Reconciliation enables the development of a sustainable democracy and nonviolent conflict management strategies (40). Key to creating such a democracy is the regular and active participation of civil society in all efforts of reconciliation (Ciociari and Ramji-Nogales 199).

Charles Villa-Vicencio recognizes reconciliation not only as a goal, but as a process. Reconciliation necessarily requires finding ways to bring people together over what are often "'historical and entrenched barriers of suspicion, prejudice and inequality" (Villa-Vicencio, as qtd. in Maddison 46). The task of shifting values, of instilling a "“willingness to venture beyond the promotion of rigid identities"” (46) and cultivating energy to imagine and pursue "'a different set of relations with one's adversaries and enemies"' (46) is no brief or straightforward venture. This is a goal that requires patience, and the understanding that steps taken today may not immediately lead to visible outcomes or changes, but that they lead towards the creation of a foundation upon which future generations will build. 
In summary, then, truth and reconciliation processes are conceived as a means of transforming conflict in ways that bring it into nonviolent social and political arenas and modes of being (Muldoon, as qtd. in Maddison 53). We may think of conflict transformation as the broad objective. Under that umbrella are "truth" processes (dialogue, memory retrieval and memorialization) and "reconciliation" processes (forgiveness and apology, reconciliation). While the truth processes must begin before the reconciliation processes, they need not be completed before the reconciliation processes can begin. Since each of these elements is a process, each is ongoing, just as the process of conflict transformation to which they contribute is ongoing. Together, these processes accomplish the foregrounding of repressed information (53). They politicize the conflict that led to the violent breach in the social fabric by accommodating it in political discourse and practices. A successful truth and reconciliation process is the means by which a nonfactual national narrative is successfully challenged and replaced by a factual counter-narrative. Such a process can empower citizens to create a stable and healthy democracy.

\section{f. The Problem of Impunity}

Conceiving and implementing truth and reconciliation processes is particularly challenging in circumstances that have been characterized by impunity for a prolonged period of time. The first set of challenges arises from the passage of time since the original conflict. The argument may be made that truth and reconciliation become meaningless when most of the perpetrators and most of the victims have died due to the passage of time. Who remains to be held accountable, and who to be recognized as victims? The answer is that profound, extensive, officially sanctioned violence within a 
nation creates intergenerational scripts which continue to compromise the health of society long after the actual perpetrators and victims have died (Maddison 69). The "complex emotional burdens" of violence on families and communities are lasting (69). Trauma, and the accompanying "memories of historical violence," can be transmitted intergenerationally, "influencing present and future perceptions of the other community" and fueling "volatile" political environments that are found in divided societies (Staub and Pearlman; Hutchison and Bleiker, as qtd. in Maddison 69). Guilt and a sense of responsibility may also be handed down from one generation to the next (Barkan; Maddison, as qtd. in Maddison 69). Further, as discussed above, unmanaged conflict is not exhausted by a singular explosive expression, but continues to manifest itself, sometimes in periodic direct violence, but almost always in structural and cultural violence expressed as injustice, exclusion, inequality, prejudice, ignorance, and discrimination (Ramsbotham, as qtd. in Maddison 26).

Susan Opotow examines the difficulty of reconciliation in post-conflict situations when crimes against humanity (such as mass murder) are either explicitly or implicitly excused, or when it becomes expedient to "look the other way," and impunity is institutionalized (Opotow 150). Institutionalized impunity creates a culture of impunity in which abuses go unpunished and justice is absent (150). Opotow identifies three interrelated facets of impunity—structural impunity (relating to "institutional structures of the state, such as constitutional authority conferred on the army for internal security"), strategic impunity (that is, "specific procedures and structures adopted to prevent criminal investigation or prosecution"), and political/psychological impunity (the "manipulation of fear, distrust, and isolation among citizens," the "most poignant and 
tragic of all aspects of impunity") (151). She discusses the relationship between violence and impunity, citing Johann Galtung's distinction between direct and structural violence (151). Direct violence is understood as violence that is explicit, overt, and committed by specific people upon specific victims (151). Structural violence is imperceptible, upheld in societal structures as "the way things are done," and manifests as inequalities structured into society (such as access to social goods and services that promote wellbeing only for some members of society) (151). In cultures of impunity, these forms of violence are indistinguishable (152).

Impunity is dependent on a set of relationships that guard and uphold it, lending social support to institutional bodies and actors that should otherwise be punished for perpetrating crimes against humanity (Opotow 153). These relationships, called collusion, depend on cooperation and mutual protection of shared interests (that is, not being punished) in groups of perpetrators of direct violence, as well as requiring the support of larger networks (154). Police officers, for example, might participate in corrupt or violent behavior. They depend on other institutions, such as the court system, to "protect them from accountability" (154) and to maintain the status quo from which they benefit. This builds a moral framework in which violence towards some people is acceptable and appropriate (155). This "moral exclusion" (155) rationalizes harm inflicted on those perceived to be beyond the scope of justice (156), dehumanizing victims and members of less dominant groups while bolstering dominant group members' perceptions of their own dignity, humanity, and worthiness for access to resources and protections of the state (156). 
Institutionalized, longstanding impunity becomes a politically expedient strategy. It has serious impacts on how different groups view one another and their willingness to work with one another, creating difficulty in rallying the necessary institutional bodies to participate or encourage or allow TRCs to begin taking shape (Opotow 160). Members of dominant or "in-groups" (156) are coming from a place where non-dominant (or "outgroup") members are viewed as so irrelevant that they do not have the same claims to fairness, justice, or resources (156). If impunity is longstanding, in-group members may have come to minimize and lose their grasp of the severity of their crimes (157). Violence is glorified and supported by institutions and individuals. Summoning the will to feel prepared to potentially face the loss of these protections and benefits is immense and complicated. While to some extent TRCs take place at the level of individuals, it is also key to their success that they be met with institutional support and guidance, so that longterm goals and changes can be addressed (Maddison 268). Parties that have emerged victorious from conflicts can thwart attempts to prosecute violators of human rights (Opotow 160). They may negotiate amnesties and pardons as preconditions for peace talks, thereby negating the possibility for justice (160).

For out-group members, this culture of moral exclusion and impunity is a source of pain, anxiety, and grief. For many survivors of Pol Pot's regime in Cambodia, for example, Khmer Rouge impunity is a "source of continuing anguish" and an "obstacle to personal healing" (Ciorciari and Ramji-Nogales 198). Reconciliation efforts thus face extensive challenges in "cultivating a new attitude towards others" as the basis for addressing "the major material and structural challenges" that perpetuate war and violence in post-conflict societies (Villa-Vicencio, as qtd. in Maddison 46). The success 
of the process hinges on changing the perception of some members of society as beyond the reach of justice, and of instilling the urgency for remorse in a system that minimizes these experiences by supporting perpetrators of violence (Opotow 156).

\section{g. Discourse Analysis in Understanding Truth and Reconciliation Processes}

Discursive strategy analysis and construction is at the heart of truth and reconciliation. The fundamental task of truth and reconciliation processes is to identify and call into question the accuracy of dominant national narratives which deny, obscure, or falsify governmentally-sanctioned episodes of violence on a massive scale. The identification of these narratives depends on the close reading of cultural texts, including publications, films, and other public and private discourse. Truth and reconciliation processes can be seen as attempts to constitute opposing narratives to challenge and correct a nonfactual dominant narrative. The discursive choices constituting both dominant and challenger narratives are highly strategic.

Maddison touches on the rhetorical dimension of truth and reconciliation in her analysis of how the continuity of conflict post-catastrophe can be either hidden or clearly identified. The ways post-conflict violence is discursively portrayed should have a role in how reconciliation and conflict transformation efforts are imagined and structured (Maddison 33). Violence is spoken of in different terms when it is thought of as being officially over, although there are certainly still "continuities of violence" between the war and postwar intervals (Schuld, as qtd. in Maddison 33). Similarly, narratives have a role in curtailing violence by bringing conflict into the political arena (Muldoon, as qtd. in Maddison 53). This happens "not because there is sudden agreement about past 
wrongs, but because marginalized groups politicize those past actions by renaming them as injustices" (53).

Martin Reisigl and Ruth Wodak have designed a Discourse-Historical Approach (DHA) to critical discourse analysis. Their approach is adaptable for use in a truth and reconciliation context. The questions they devise in examining discursive strategies are useful in the close reading of pertinent cultural texts.

1. How are persons, objects, phenomena/events, processes and actions named and referred to linguistically?

2. What characteristics, qualities and features are attributed to social actors, objects, phenomena/events and processes?

3. What arguments are employed in the discourse in question?

4. From what perspective are these nominations, attributions and arguments expressed?

5. Are the respective utterances articulated overtly; are they intensified or mitigated?

(Reisigl and Wodak 93)

The answers to these questions illuminate the speaker's discursive strategy as to the five dimensions identified by Reisigl and Wodak. All five dimensions will be present in every discourse. The first, nomination, is the discursive construction of actors and events. The second, predication, is the positive or negative qualification of actors and events. The third, argumentation, either justifies or questions truth and rightness claims. The fourth, perspectivization, positions the speaker's point of view, showing either involvement or distance. The last, intensification and mitigation, modifies the force of 
assertions made, one way or the other (Wodak and Meyer 93). In the context of discourse about officially-sanctioned killing of civilians on a mass scale, calibrating a speaker's discursive strategy enables the analyst to assess the relative strengths and vulnerabilities of the dominant national narrative as well as of competing narratives. This analysis is ground zero in accurately understanding the contours and progress of truth and reconciliation processes.

\section{Primary Source Materials}

Until the release of The Act of Killing, the events of 1965 were relatively unknown both within Indonesia and to the international community. Oppenheimer's two films have provided an important precursor to the possibility of conceiving and executing an official truth and reconciliation process. The films and other primary source materials reveal the contours that a process in Indonesia might take by disclosing the dominant narrative, challenger narratives, and current discourses in Indonesia about these completing narratives. Taken together, Oppenheimer's films provide a truly extraordinary range of perspectives, from articulations of the dominant national narrative to fledgling counter-narratives.

As primary texts, The Act of Killing and The Look of Silence are amenable to deep analysis using the discourse-historical approach to discourse analysis designed by Reisigl and Wodak as a means to examine how the perpetrators and the victims discursively construct narratives that either support or counter the dominant national narrative of the killings. The films are also susceptible to examination according to theoretical and conceptual frameworks advanced in secondary source materials by Ciorciari and RamjiNogales, Maddison, Opotow, and others. This serves as a way to explore how different 
processes integral to reconciliation are or are not taking shape, what obstacles they may face, and what considerations are appropriate in terms of larger scale reconciliation in Indonesia's context of institutionalized impunity. Other primary source materials are used as counterpoints and substantiating documents, including reports and transcripts issued by the 1965 People's Tribunal in the Hague and articles in contemporary periodical literature. 


\section{Methodology}

My approach to this inquiry is to draw on my background in the field of English to conduct critical discourse analyses of Joshua Oppenheimer's films. The study of English as a discipline involves the central tasks of creating, identifying, analyzing, challenging, and revising texts and narratives. Essential to these tasks are considerations of discursive strategy and of how narratives function in a culture. Treating Oppenheimer's documentaries as texts, I identify and analyze the dominant narrative, as well as counter-narratives, about the events of 1965 in Indonesia. My main interest is in how the already-existing dominant narrative is discursively reconstructed and reinforced (and how that impacts people's understanding of these events) as well as how counternarratives are taking shape to displace the narrative justifying the state-sponsored slaughter of civilians. This narrative revision is an indispensable step toward a reconciliation process.

Critical discourse analysis is "characterized by the common interest in demystifying ideologies and power through the systematic and retroductable investigation of semiotic data (written, spoken or visual)" (Wodak and Meyer 3, original emphasis). Discourse is seen as a form of "social practice," in that it is indicative of dialectical relationships between "a particular discursive event and the situation(s), institution(s) and social structure(s), which frame it" (Fairclough and Wodak, as qtd. in Wodak and Meyer 5). Discourse is both "socially constitutive" and "socially conditioned"- "it constitutes situations, objects of knowledge, and the social identities of and relationships between people and groups of people. It is constitutive both in the sense that it helps to sustain and reproduce the social status quo, and in the sense that it contributes to transforming it" (6). 
Critical discourse analysis is an analytical method well suited to an inquiry into how a fictitious and unjust social narrative is upheld, and how it might be subverted.

My inquiry into truth and reconciliation processes, and the shape they might take in Indonesia, is structured around an adapted version of the discourse historical approach (DHA) to critical discourse analysis laid out by Martin Reisigl and Ruth Wodak. The DHA is centered on trying to create "a theory of discourse by linking fields of action (Girnth, 1996), genres, discourses and texts" (Wodak and Meyer 26). The DHA follows Mouzelis' recommendations for social research, namely to "develop conceptual tools adequate for specific social problems," focusing in particular on the field of politics, where it "develops conceptual frameworks for political discourse" (26). I have condensed Wodak and Reisigl's original outline for the DHA to better suit the scale of this particular project. They propose an 8-step model, which I have modified to a 5-step model by combining some steps and omitting others. I use Reisigl and Wodak's methodology to examine how the events of 1965 are discursively constructed in Oppenheimer's documentaries and various contextual documents. These findings are assembled in tables located in Appendices B and C. The adapted steps from Reisigl and Wodak's approach are listed below. ${ }^{1}$

After analyzing primary source materials with this method, I then apply concepts discussed above from secondary source materials to Oppenheimer's films, examining the roles of dialogue, impunity, memory and memorialization, and reconciliation in conflict transformation in the Indonesian context. What aspects of these major processes do the primary source materials exhibit? How are they discursively constructed? What might that indicate overall regarding the presence of preconditions for conflict transformation 
and reconciliation in Indonesia? I draw conclusions from the analysis using these theoretical structures. I also utilize pieces of mainstream Indonesian journalism and other reports and proceedings relating to the events of 1965-66 to contextualize Oppenheimer's films in public discourse. Finally, I assess where things currently stand in Indonesia in terms of readiness to take on a reconciliation process, and imagine how this process might proceed.

The steps in the adapted discourse-historical approach to critical discourse analysis are as follows:

1. Activate and consult preceding theoretical knowledge (i.e. recollection, reading, and discussion of previous research). Specifically, research about the purpose, methodology, and application of truth and reconciliation processes.

2. Systematic collection of data, context information (various discourses and discursive events, social fields as well as actors, semiotic media), and primary source materials.

3. Evaluation of primary source materials using discourse analysis strategies outlined in Wodak and Reisigl's chapter on the Discourse Historical Approach. Identify and analyze discursive strategies which shape the dominant and insurgent narratives concerning 1965. Discursive strategies are as follows:

I. Nomination - the discursive construction of actors and events. How are persons, objects, phenomena/events, processes, and actions named and referred to linguistically? 
II. Predication - The positive or negative qualification of actors and events. What characteristics, qualities, and features are attributed to social actors, objects, phenomena/events and processes?

III. Argumentation - The justification of truth and rightness claims. What arguments are employed in the discourse in question?

IV. Perspectivization-Positioning of the speaker's point of view, showing either involvement or distance. From what perspective are these nominations, attributions, and arguments expressed?

V. Intensification and Mitigation-Modification of force of assertions made. Are the respective utterances articulated overtly; are they intensified or mitigated?

(Reisigl and Wodak 93).

4. Draw conclusions from the analysis.

5. Assess where Indonesia stands on the road to reconciliation. Imagine how Indonesia might proceed in taking steps toward a reconciliation process. 


\section{Analysis}

The dominant narrative of the massacres was constructed and reinforced over the span of Suharto's rule. Suharto launched a propaganda campaign that "provided the trigger for the mass killings of 1965-66" (McGregor). Following the crushing of the September 30th Movement, the army worked to "shut down Communist and other leftist publications," and pro-army newspapers began to dominate the media (McGregor). These newspapers "set about spreading grisly accounts of the murders of the army leaders, claiming their bodies had been mutilated prior to and after their deaths" (McGregor). The retaliatory killings of civilians were subsequently minimized and misrepresented in school textbooks, further supporting the formation of the dominant narrative (McGregor). Within weeks of the failed coup, the military had produced a book emphasizing the PKI's responsibility and "their alleged depravity during the kidnapping and killing of the seven army martyrs" (McGregor). A propaganda film reenactment of the killings was shown repeatedly on all television stations (McGregor). The regime designated October 1st as "Sacred Pancasila Day" - a commemoration of the day the national ideological principles had been saved from a communist plot (McGregor). After the fall of Suharto in 1998, a few brave people inside and outside of the government started challenging the dominant narrative, although their efforts were consistently met with obstruction, threats, and actual violence (McGregor).

In 2012, two events brought simmering fears and anger regarding the 1965 massacres in Indonesia to the forefront of public consciousness. One was the release of a report by Indonesia's National Commission for Human Rights (Komnas HAM) on the results of its investigation into human rights violations in 1965 . The second was the 
release of documentarian Joshua Oppenheimer's film The Act of Killing. Two years later, in 2014, Oppenheimer released a companion film, The Look of Silence, also dealing with the events of 1965. In November 2015, an International People's Tribunal convened in the Hague and took four days of testimony concerning those same events. Each of these seminal texts has been reported and discussed in the popular press. Oppenheimer's provocative films, in which perpetrators of government-sanctioned mass murder frankly discuss their crimes, have become the focal point of both national and international conversations about whether and how Indonesia's government might institute a truth and reconciliation process.

\section{Joshua Oppenheimer's The Act of Killing and The Look of Silence}

The Act of Killing and its companion film, The Look of Silence, focus on the prolific yet little known Indonesian massacres of ethnic Chinese, suspected communists, alleged enemies of the state, and others in 1965-66. Though quite different in approach, with the first providing a platform primarily for the perpetrators, the second for the victims, the films together document the continuing damage resulting from the lack of accountability and of a government-sponsored process for truth and reconciliation. Oppenheimer discovers that the perpetrators, though triumphant, live in fear. They fear the surviving family members of the murdered and the possibility of a correction to the national narrative glorifying their brutality. The victims live in despair and in fear of suffering the same fate as their family members. The combined effects of structural, strategic, and political impunity deepen the chasm between victims and perpetrators. Oppenheimer's films horrifyingly document the resulting deep, pervasive unease on both sides. The current situation in Indonesia demonstrates Maddison's hypothesis that 
conflict is not resolved with the end of open hostilities. Instead, it goes underground,

flaring up from time to time. 2

The films document the dominant cultural narrative concerning the events of 1965 through the voices of the killers and their government collaborators, as well as the way insurgent narratives bump up against the dominant narrative through the voices of victims. The filmmaker constitutes his own independent discourse, which is also highly relevant to the question of what form truth and reconciliation processes might take.

\section{a. Discourse analysis of The Act of Killing}

The Act of Killing is a discursively complex and intriguing text. It is structured not just around Oppenheimer's interviews and interactions with former killers, but also around the killers' own reenactments of their involvement as gangsters and death squad leaders in north Sumatra in 1965. The reenactments are woven through Oppenheimer's documentary to shape a portrait of one side's experience of these events. The killers' retellings of the murders are elaborately staged on the set of their own film, where they control and construct how past events should look, should be acted, and should be directed. Their taste for the cinematic is stunning. These scenes are set between interviews - sometimes in groups, sometimes in one-on-one discussions with Oppenheimer — where the perpetrators reflect on what happened in 1965, what the consequences have been, and what they think now about those events. The official narrative is continuously constructed throughout the film including in interviews with

\footnotetext{
${ }^{2}$ The conflict Oppenheimer documents is still active and dangerous, despite the passage of 50 years since the original violence took place. When government action causes a breach in the social fabric which creates a deeply-divided society, only a government-sponsored truth and reconciliation process effecting conflict transformation can render the conflict "safe."
} 
public figures such as Ibrahim Sinik, a famous newspaper publisher in Medan; in Anwar Congo and Herman Koto's appearance on a local news channel; and in Vice President Jusuf Kalla's address to a paramilitary rally. Sometimes worried about sounding too harsh, these figures will turn to the camera and assure their invisible audience, and the film crew, that they aren't really that violent normally, that this was an extraordinary situation that called for extraordinary action (Killing).

One of the most startling constructions of the national narrative is Vice President Jusuf Kalla's. He addresses Pemuda Pancasila (Pancasila Youth—-the massive youth paramilitary organization of which many of the killers are high-ranking founders and esteemed members), exhibiting the five discursive characteristics identified by Wodak and Reisigl. In his nominative and predicative discursive choices, Kalla constructs the killers as courageous national heroes and their crimes against civilians as the salvation of Indonesia's democracy. Kalla praises the preman (Indonesian for "gangster", derived from the English "free-man") spirit of Pemuda Pancasila (Killing). The nation, Kalla says, "needs free men! If everyone worked for the government, we'd be a nation of bureaucrats; we'd get nothing done! We need free men to get things done" (Killing). The "things" Kalla is referring to are the killings of hundreds of thousands of Indonesians. Kalla's argumentation elaborates a narrative in which heroic citizens did what had to be done when government alone could not act. He perspectivizes himself as an involved admirer of civilian heroes rather than distancing himself from their deeds. Kalla intensifies his narrative by engaging in this brazen celebration of mass executions of civilians in an open-air venue with thousands of paramilitary affiliates in attendance. This public embrace by a senior government official further intensifies the rightness claims of 
the official narrative because it is a promise of perpetual collusive relationships and unconstrained impunity for the killers.

At the beginning of The Act of Killing, Anwar Congo, a former gangster and death squad leader, shows Oppenheimer a rooftop where he killed thousands of men. In Anwar's discursive choices in repeating the national narrative, he constructs himself and the other killers as brave heroes and their victims as weak and unworthy. Anwar proudly demonstrates his preferred way of killing — strangling the victim with a wire—-for Oppenheimer. Anwar's argumentation justifies the truth and rightness claims of the dominant narrative. In his perspectivization of the slaughter, Anwar posits himself as fully involved. However, Anwar (self-servingly?) mitigates the force of his assertions by telling Oppenheimer that he drinks and takes drugs and goes out dancing to forget what he's done (Killing). "I've tried to forget all this with good music" he says. "Dancing [...] A little alcohol, a little marijuana... A little... what do you call it? Ecstasy... Once I'd get drunk, I'd 'fly' and feel happy" (Killing). He then flippantly proceeds to perform his cha-cha-cha. Anwar further mitigates his rightness claims by talking about nightmares he has about the murders. He tells his friends that he knows these dreams "come from what I did... killing people who didn't want to die. I forced them to die" (Killing). By mitigating the force of the national narrative, Anwar opens the door to a challenger narrative in which the violence is condemned.

In a particularly jarring scene from the killers' reconstruction of the murders, Anwar plays the part of a communist being interrogated. He stops the scene, short of breath, and says he can't go on. Oppenheimer plays the scene back to him. Anwar recalibrates the perspectivization of his discourse, distancing himself from the scene, in 
this way further mitigating the force of his justification of official claims of rightness. Anwar asks if his feelings when playing the part of a communist suspect—paralyzing fear and hopelessness-were what the people he killed had felt (Killing). Oppenheimer speaks to him from behind the camera, saying that Anwar's victims felt much, much worse, because Anwar knew it was only a reenactment, whereas his victims knew they were actually going to be killed (Killing). At the end of the film Anwar and Oppenheimer return to the rooftop where earlier Anwar danced, but by this point, after making his own movie reenacting his crimes, Anwar is unable to continue boasting about the murders. $\mathrm{He}$ begins to retch violently.

Oppenheimer's exploration of the inward price the killers have paid for their outward impunity is complemented by his examination of the suffering of surviving family members. Whereas the killers live in fear of accountability, yet suffer from the lack of it, the victims live with the rage, hatred, bitterness, grief, and despair of justice denied as well as with the terror of suffering the same fate as their murdered family members at the hands of killers who are still prominent citizens in their communities. The victims, both present and absent, tell the insurgent narrative about 1965. Absent victims speak through the killers, who gleefully report how the victims tried to flee, wept, and begged for mercy. In these accounts of the last words of the dead, we hear their predication of themselves as innocent victims, of the killers as savages, and of the massacres as a wanton campaign of terror. The counter-narrative that arises from these reported statements powerfully undermines the dominant narrative.

A counter-narrative also emerges from within the confines of an articulation of the dominant narrative by an actor in the killers' film. In one scene, an ethnic Chinese 
Indonesian cast member volunteers a story to be added to the project. By means of complexly dualistic discursive choices, the ethnic Chinese man constructs the episode of his stepfather's execution as humorous and appropriate. He predicates his stepfather as despicable and deserving of an ignominious death, the assassins as powerful and justified. He does not question the rightness claims of the killers. Yet his perspectivization of himself as intimately allied, not with the killers, but with his stepfather, as well as his exceedingly emotional intensification of the force of his assertions, combine to completely undermine his discursive strategy and reveal a non-strategic hidden discourse in which his stepfather is nominated and predicated as a hapless victim to be pitied; the killers are nominated and predicated as ruthless villains; and the rightness claim of the dominant narrative is challenged.

The ethnic Chinese man recounts his stepfather's execution as follows. Killers came to their home in the middle of the night and dragged his stepfather away, ignoring his mother's pleas for mercy. The next morning he discovered the body, hidden under an oil drum in the road. The man assures Anwar and the others that he doesn't mean to offend them. He tells them how funny his stepfather's death was, how hilarious the body looked in the oil drum. However, he begins to weep uncontrollably. The killers tell him that his story is too complicated, that they can't use every story (Killing). They continue shooting a scene, with the ethnic Chinese man playing the part of a suspect being interrogated. Crying and spitting, he is unable to regain his composure. He has snot all over his face as he speaks both in character, and as the child who lost his father, begging for mercy. This man's unintentional undermining of the dominant narrative through his obviously unscripted experience of inhabiting his stepfather's experience shows the 
dominant narrative to be a grotesque fabrication. For victims, adopting the dominant narrative is only possible through excruciating self-abasement.

The victims speak again in two other scenes from the film within a film, one the massacres at Kampung Kolam, a village of women and children; and the other a production number at the end of the film. The village scene, like the interrogation scene, directly juxtaposes the dominant and insurgent narratives through competing discourses. The women and children, who are untrained actors in the killers' movie, construct and predicate their characters as innocent victims of terror and their killers as brutal monsters. During a break in the filming, one of the killers actually reinforces the victims' discourse by bragging about the sexual mutilation of women murdered in 1965 (Killing). He does not offer condemnatory argumentation, perspectivize himself remotely, or mitigate the force of his discourse. He doesn't need to, because he is well within the parameters of the sanctioned national narrative. This huge area of overlap in the national and challenger narratives (the horrifying numbers of the dead, the details of the killings), which the killers do not deny, but boast of, presents the greatest hope for the ultimate reconceiving of the national narrative and transformation of the cultural conflict.

In a subtext to the stories of the killers and of the victims, Josh Oppenheimer himself advances a narrative in The Act of Killing. Dispensing with the illusion that documentaries are neutral factual statements that make themselves, Oppenheimer is actually present in the film and converses with the perpetrators at times. At other times, though he does not speak, the audience understands that the perpetrators are responding to him. Oppenheimer discursively nominates the people killed in 1965 and predicates them with compassion as innocent victims. Oppenheimer's construction and qualification 
of the perpetrators is more complex. In pointing out to Anwar on the set of the killers' film that his unease cannot be equated with the pure terror of innocent people who knew they were about to be murdered, Oppenheimer qualifies the perpetrators as morally and emotionally detached from their own actions. The viewer gathers, in listening to Adi Zulkadry's defiance of a possible international war crimes tribunal, that Oppenheimer's attitude toward the massacres has been condemnatory (Killing). Nevertheless, in listening to the ruminations of the perpetrators and in filming their reenactments, Oppenheimer accords human dignity to the killers as well as to the murdered. While his argumentation clearly questions the rightness claims of the killers, his perspectivization positions him close, engaging them intimately, not remotely. Similarly, the force of Oppenheimer's condemnation of the massacres is mitigated by his compassion for the killers.

In the production number created by the killers for the end of their movie, Anwar's victims approach him on an elaborate set complete with a chaste chorus line of dancers in costumes invoking the flag of Indonesian democracy. The victims drape a medal over Anwar's neck and thank him for killing them and sending them to heaven (Killing). Again, the dominant narrative is shown to consist of discourse constructing the killers as saviors of the nation. In reliance on the seeming immutability of the narrative, Anwar does not perspectivize himself remotely. He maximally intensifies the force of his assertions. However, the great weakness in the dominant narrative is obvious from the fact that it relies on Anwar's predication of the dead as understanding that they fully deserved the death he meted out and are thankful to him for doing so (Killing). Again, the weakness of the national narrative is that the facts are not in dispute. A mere 
discursive pivot, from justifying rightness claims to questioning them, unravels the thread of the story.

\section{b. Discourse analysis of The Look of Silence}

The Look of Silence unfolds as the story of a man seeking honesty from the men in his community who murdered his brother Ramli in 1965. Adi Rukun, an optometrist, uses his profession as a means to engage former killers in conversation, testing their eyes while probing them about their involvement in the Snake River massacres in northern Sumatra. The film is punctuated with footage Oppenheimer shows to Adi from earlier interviews with local perpetrators. In the course of the film, details of Ramli's gruesome and horrifyingly brutal murder are slowly revealed. The complex narrative that ensues is one which focuses on victims constructing a counter-narrative about the civilian massacres of 1965. As Oppenheimer and Adi confront them, the perpetrators also speak and reconstruct the dominant narrative. The insurgent narrative meets firm opposition from the killers, but a more nuanced response from the killers' families.

The killers nominate the events of 1965 , and the roles they played, predicating the violence as just and correct. In their argumentation, the killers uphold and discursively reconstitute the dominant narrative through such statements as that made by Amir Siahaan, who, when describing the murders, says that the killers should be rewarded with a cruise to America since they played a role in a matter of international politics. Siahaan's argumentation fully adopts official claims of rightness. He predicates his participation in a death squad as revolutionary and essential to the formation of democracy. Adi's son is shown learning about the killings in school. His teacher predicates the communists as 
ruthless and cruel, and instructs the children to thank men like Amir Siahaan for their "heroic struggle" to fight communism and establish a democracy (Silence).

Siahaan's predication is echoed in an NBC News report Oppenheimer shows Adi. The report features an American reporter, whose argumentation celebrates the massacres of 1965 as "the single biggest defeat ever handed to communists anywhere in the world" (Silence). He predicates the victims as subhuman by talking about entire families being "liquidated" in a "purge" lasting for sixteen months (Silence). In a bizarre misappropriation, the alleged voices of victims are used to construct the dominant narrative in an interview with a Balinese villager, who tells the American reporter (Ted Yates) that communists in the area "realized that they were wrong" and came to village leaders asking to be killed (Silence). The perpetrator perspectivizes himself so intimately and unapologetically with the dominant narrative that he has the effrontery to violate the dead in using them to support official rightness claims.

Two killers who feature prominently in the film are Amir Hasan and Inong. They appear both in the early footage Oppenheimer shows Adi, and later in face-to-face interviews Adi orchestrates. In one segment, Amir Hasan and Inong take Oppenheimer to the banks of the Snake River, where they discursively nominate the massacre, the victims, and their own roles in the killings. They predicate the slaughter as "historic," an episode within a political revolution (Silence). They specifically recall the brutal murder of Ramli on the riverbank. Each helps the other remember details of Ramli's execution. Amir goes so far in this unscripted retelling as to tell Oppenheimer where to stand to film the scene. Inong even brings a knife along to make the reenactment more "authentic" (Silence). They predicate Ramli as an enemy who had to be killed. Amir remarks, "Ramli 
was probably a good person... But what could we do? It was a revolution" (Silence). Under the banner of revolution, Amir Hasan and Inong argumentatively justify the rightness claim of the official narrative. They predicate themselves as agents of the revolution, perspectivizing themselves close to the killing. Why not? Within the context of this narrative, the killings were completely legitimate. Nevertheless, a note of unease comes through in their admission that Ramli was "probably" a good person. This insight mitigates the force of the killers' assertions and complicates their predication of themselves and their victims. The force of their assertions is further mitigated through Ramli's voice, which is strangely and hauntingly present as Inong and Amir Hasan mimic his cries for help before they killed him.

The dominant narrative is discursively reconstructed again in Adi's interview with Samsir, another killer. Samsir's adult daughter is also in attendance for this interview, and her presence interestingly complicates the narrative that unfolds. Samsir nominates killers, victims, and incidents and predicates them predictably. He seems intimately perspectivized as he brags of his heroism in bringing a woman's head to a market to intimidate ethnic Chinese Indonesians (Silence). However, Samsir subverts his argumentative justification by reporting that he had to drink blood from the bodies of the murdered in order to keep from going crazy. As with the admission by Amir Hasan and Inong that Ramli was probably a good person, Samsir's revelation about drinking blood to ward off madness mitigates the force of his simplistic predications and rightness claims. Samsir's daughter is clearly uncomfortable throughout this discussion as she apparently learns these details for the first time, but she still tries to defend her father. Adi tells Samsir and his daughter that his brother was killed by a death squad. The daughter 
immediately steps into her father's discourse to perspectivize herself remotely and substantially mitigate his rightness claims. She asks Adi to forgive her. Adi tells her it isn't her fault that Samsir is a murderer. The daughter offers her own predication of her killer-father. She asks Adi for his compassion to look on her father as an old man, and to think about them as family.

Samsir's daughter's sentiment— to think of one another as family—is echoed by Amir Hasan's wife. Amir Hasan has died in the interim since the interview in which he and Inong stand on the riverbank reporting the details of how they killed Ramli. In a later scene, Oppenheimer and Adi interview Amir Hasan's wife and sons in their home. Like Samsir's daughter, Amir Hasan's wife is uncomfortable with the truth claims of the dominant narrative and recoils from predicating her husband as a hero for his crimes. She perspectivizes herself remotely, claiming to have no recollection of her husband ever saying he was involved in the killings - despite her presence in the earlier interview in which her husband showed Oppenheimer a book he wrote and illustrated "to bring [his death squad involvement] to life" (Silence). Oppenheimer has brought the book along. Amir Hasan's wife looks disturbed as they go through it, and insists she's never seen it before. Oppenheimer reminds her that she was there when her husband showed him the book and gave him a copy. Her discursive argumentation continues to question not only the rightness claims of the official narrative, but also the truth claims. "We know nothing about this. My husband never told us. We never read the book. My husband never said he killed anyone" (Silence). One of her sons supports this - "we didn't know what he was doing... he never told us" (Silence). The family's discourse, so different from that of the killers, shows profound discomfort with argumentative assertions of rightness, employing 
distant perspectivization and mitigation of the force of all aspects of the dominant narrative.

Oppenheimer persists with challenging the authenticity of Amir Hasan's family's attempts at argumentative disputation of the dominant narrative's truth claims and remote perspectivization of their killer-father and themselves. He confronts them, "I don't want to make you uncomfortable, but Adi is here to speak openly" (Silence). One of Amir Hasan's sons responds, "Everyone around here is friends. Even if their parents were killed, we're all good friends. Now the wound is open, because Joshua makes this film, and my father wrote this book-the wound is open" (Silence). He grows menacing as he asks Adi, “ Otherwise you wouldn’t know me, right?” (Silence). Adi replies, “Of course I knew. I knew all about this family. All the victims' families know who the killers are. But that doesn't mean we want revenge" (Silence). This extraordinary exchange reveals the troubling persistence of the conflict, which is no longer overt, but clearly structural in nature and still dangerously untransformed. It also reveals the openness of families of death squad members to the challenger narrative. Whereas their husbands and fathers perspectivize themselves intimately in brazenly bragging of their murderous exploits, the wives and children are already constructing a discourse that could become a bridge to a successor narrative. As Adi and Oppenheimer are about to leave her home, having been threatened by her sons, Amir Hasan's wife tells Adi : “Adi, we apologize. We feel the same way you do" (Silence).

The official narrative perpetrators reconstruct in The Look of Silence is maintained by means of excuses and threats. Each killer can boast about his involvement, about the ways he most preferred to kill people, when he is talking about victims as a 
faceless, nameless mass. When confronted by Adi, and by the story of his brother Ramli, they quickly backpedal, adjusting their perspectivization from intimate to remote, trying to find someone else to predicate as responsible. It was the orders of their commanding officers; it was something the government told them to do; the squad they were in charge of was killing people in a different location and didn't take part in the killings at Snake River. Although they do maintain their claims to rightness, the killers also seem to inhabit a delusional world where they thrive off everyone's fear of them, while simultaneously believing that nobody knows about the specific roles they had in committing the violence.

The viewer hears several paramilitary death squad members and their families reconstructing the dominant narrative and variations in The Look of Silence, as they are confronted by Adi and Oppenheimer. But at the heart of the film are Adi and other victims constructing a counter-narrative about the events of 1965. Adi predicates his brother's killers as murderers, but also as his neighbors. His approach in interviewing them is not to punish or seek revenge, but to find acknowledgement of the crimes they committed and to receive their apology. His stance is that if he and they can see one another's humanity, they can move forward and live together as neighbors, the rift in the community thus healed.

Adi interviews Kemat, a man who survived being killed at Snake River by jumping out of a prisoner transport truck. Kemat tells Adi that the people in town were too scared to watch the victims be lined up and marched out of town. He remembers how Ramli screamed for help, saying, “They're going to kill us all!” (Silence). Adi and Kemat go to the banks of the Snake River together, retracing Inong and Amir Hasan's steps. As they step off the road and onto the killing field, Kemat nominates the victims who died 
there and predicates them as his "friends and family" (Silence). Curiously, Kemat perspectivizes himself remotely, saying that he knows God will punish the perpetrators in the afterlife. "It is not for us to punish," he says (Silence). Kemat maintains that the past is past. He doesn't want to remember what happened. "It's covered up. Why open it again?" he asks (Silence). "The wound has healed" (Silence). Kemat was intimately involved in the killings, narrowly escaping with his life. He does not question the truth and rightness claims of the counter-narrative, but unexpectedly mitigates their force by questioning the purpose of advancing a narrative in opposition to the official one. Kemat mitigates his feelings, his involvement, his need for honesty and justice, all out of fear of the possible consequences of reopening old wounds. Kemat's underlying fear betrays the fallacy of his argument that the wounds have healed. Adi, who was not born until two years after his brother's death, and is therefore less intimately connected to the events than Kemat, takes on a more involved role, perspectivizing himself closely and intensifying the truth and rightness claims of the counter-narrative.

Adi's mother Rohani, like Kemat, perspectivizes herself distantly. While she nominates the players and slaughter, predicating the killers as villainous assassins, the victims as innocents, Rohani cautions Adi against getting too involved (Silence). She mitigates the intensity of the challenger narrative's truth and rightness claims by warning Adi about the danger of reawakening old tensions. Rohani tells her son to take a club or knife along to his interviews to defend himself in case the killers try to kidnap him. She prays to Ramli's spirit to forgive her for letting the killers take him away. Like Kemat, Rohani tells Adi that the killers, their children, and their grandchildren will all be punished in the afterlife (Silence). Rohani's discursive mitigation, like Kemat's, only 
proves the exact opposite of what she is asserting. If the conflict were really over, she would have no reason to fear the consequences of a challenge to the dominant narrative.

The telling of the final chapter in Ramli's story reveals a peculiar discursive mitigation that poignantly calls the dominant narrative's rightness claims into question. Friends and neighbors took Ramli prisoner and beat him, grievously wounding him. $\mathrm{He}$ managed to escape, covering his open abdomen with one hand as he crawled home. He asked his horrified mother to make him a cup of coffee, but by the time the water had boiled, his killers were at the door. Rohani recounts begging them to let her take care of Ramli. She tried bribing them with a cow, but they were adamant. They told her they were going to take Ramli to the hospital. Rohani tells Adi that she knew this was a lie; she knew they were going to kill Ramli (Silence). But somehow in that moment, even though they all knew the truth of what was about to unfold, the killers wouldn't tell Rohani explicitly that Ramli was going to be executed for being a communist. They made up a lie about something more compassionate, perspectivizing themselves remotely from the condition Ramli was already in because of them as well as from the fate he was about to meet at their hands. This lie mitigates to the point of denial the force of the killers' rightness claims. Had the men who came to take the mortally wounded Ramli away been sure that what they were doing was right, they could have told his mother so. They could have told themselves so. The fact that they did not reveals a fatal weakness in the dominant narrative's rightness claims. The killers were ashamed of what they had done and what they were planning to keep doing, but they were going to do it anyway, so they invented a story to make it bearable. 
In The Look of Silence, as in The Act of Killing, the dominant and challenger narratives don't diverge at the facts, but at the rightness claims. That is, while the facts are not widely taught or publicized, everyone who knows anything about 1965 knows that hundreds of thousands of civilians were executed by paramilitary killing squads. Documents must be collected, and interviews conducted, to ascertain exact numbers, dates, places, and identities of killers and killed. But this is not the area of dispute. The dispute is about what the facts mean. Were the killings justified in the defense of a democratic Indonesia? Are the killers the fathers and heroes of Indonesia's democracy? The official narrative, maintained through successive acts of discursive reconstruction backed by the prestige and power of the government, answers these question in the affirmative. The counter-narrative repudiates and deplores these rightness claims.

2. Indications of Indonesia's Readiness for a Truth and Reconciliation Process from

\section{Primary Source Materials}

\section{a. Conflict Transformation}

Conflict resolution is not a linear process, but rather necessitates the initiation of conflict management strategies that unfold in a way that is cognizant of social inequalities and tensions (Maddison 58). Conflict is never really over or completely resolved. It always finds new ways of expression. In a situation of impunity like Indonesia's, conflict is tangled in collusive relationships that benefit from governmental support. The key to building stable societies is to develop relationships where collusion is not tolerated, and forge strategies that allow conflict to be expressed without violence. As stated by Maddison, reconciliation attempts unfold in contexts charged by "problematic historical events" that are still very much alive in the cultural consciousness (57). It is 
clear from Oppenheimer's films that the insistence that "the past is past" is, in fact, very far from the truth. Laksmi Pamuntjak writes in The Guardian that since the fall of Suharto in 1998, Indonesians have vigorously "indulged their new thirst for alternative readings on 1965," to whatever extent they have been able (Pamuntjak). Oppenheimer's films are one piece of a body of other texts, including literature and memoirs, that have been created toward this goal.

As can be seen from the films, the events of 1965-66 in and of themselves are a continuing source of damage caused by unresolved conflict. The unaddressed emotions are repressed and give rise to hostility and fear. This is perhaps most clearly demonstrated through the predication of the killings as a "wound" that is at once historical and current. Kemat, the survivor, and one of death squad member Amir Hasan's sons, both use this term when talking about 1965. For Kemat to predicate his own narrow escape from being murdered as a wound - that is, as something that has had lasting and profound and negative impacts on his life and his community-is fitting. The trauma of his close involvement is surely a painful and heavy wound. The mendacious justification of so many murders must also be painful. But for Amir Hasan's son, this use of the word "wound" seems an interesting choice. Is the weight of this wound, which both men claim (in spite of all evidence to the contrary) has "healed," and is not in need of reopening or disturbance, shared equally between them? Why do they both use this word, when their experiences of history are so vastly different? It is clear that there are lasting impacts from impunity and unreconciled divides between neighbors that harm society across the borders of victim and perpetrator. 
The evidence of systemic violence, and the sense that the apparatus of government will advantage the perpetrators and their supporters, but will disadvantage, and exclude from all protection, the proponents of a challenger to the national narrative, is made evident through the fact that Adi Rukun and his family had to be relocated after The Look of Silence was made (Stevens). Adi's queries into the past were made at a great personal risk. Many of the Indonesian cast and crew members who worked on The Act of Killing and The Look of Silence are "afraid to be openly associated with it," and are listed anonymously in the credits (Kwok "Movie, Books"). The ongoing persecution and intimidation of survivors and their families has become structural, as has the conveyance of the national narrative to a new generation. The climate surrounding the killings and upholding Suharto's narrative was tense. It was difficult for citizens in communities impacted by the killings to speak out or express sympathy to victims due to Suharto's enduring anti-communist campaign and to the fear of being labeled as communists and facing severe social repercussions (McGregor). Beginning in the 1980s, Suharto's New Order government implemented the so-called "Clean Environment Policy" — a set of discriminatory practices that barred the children and grandchildren of those "allegedly connected to the 30 September Movement" from working as teachers, lawyers, journalists, civil servants, or members of the military (McGregor). In her closing statements from the International People's Tribunal in the Hague, Prosecutor Silke Studzinsky applauded the courage of the survivors who "dared" to travel to the Netherlands to testify about the original crimes, as well as facing discrimination and stigmatization in contemporary Indonesian society (Studzinsky). It is likely that those 
who testified faced serious repercussions at home as a result of their involvement in the tribunal.

Pamuntjak notes being taught—like Adi's son, with "no room for other interpretations"- that all Communists were atheists and enemies of the state, and that "the defeat of the Indonesian Communist party was crucial to the survival of the nation" (Pamuntjak). This construction, Pamuntjak says, has produced "a generation schooled in silence and apathy" as well as "successive generations that are wholly ignorant" of their own history (Pamuntjak). She references a survey published by the Jakarta Globe in 2009 which showed that "more than half of the respondents comprising university students in Jakarta had never even heard of the mass killings of 1965-1966" (Pamuntjak). The misrepresentation of this chapter of history constitutes a further, more subtle type of aggression and violence. This can be seen in The Look of Silence when Adi's son's teacher does not mention the killings that took place locally at the Snake River. Victims' voices and experiences continue to be routinely ignored.

The trauma survives because it is intergenerational. This is seen in the ethnic Chinese man's response to portraying a communist suspect on the set of the killers' movie in The Act of Killing. Recognizing the trauma that victims and survivors live with daily in her closing statements from the tribunal, Studzinsky quotes Jean Améry, a survivor of Auschwitz, who said: "Anyone who has been tortured remains tortured. Anyone who has suffered torture will never again be at ease in the world. The abomination of annihilation is never extinguished" (Studzinsky). The trauma of coming face to face with the killers and torturers of one's family members daily is an act of violence. The widespread ignorance of crimes against humanity is an act of violence. The 
repression of counter-narratives and alternate tellings of history is an act of violence, and it compounds this trauma on future generations of both victims and killers.

If Maddison's theory that conflict does not cease, but simply continues after an episode of catastrophic violence, is supported by the post-conflict situation in Indonesia, then the next question is whether there are indications that the conflict is being transformed. That is, is the conflict being brought into the political sphere where it can be managed without violence? What does it mean, for example, that a government official recently praised the paramilitary organization responsible for many of the executions for doing what governments cannot? There is an implicit acknowledgement here that democratic governments cannot engage in the killing of citizens without due process provided in the context of authorized criminal justice processes. It seems clear that the politicization of the conflict has not happened at all or is in its infancy. Here we have a government official coming right out and saying_ " "this type of slaughter is necessary, but it has to be done by paramilitaries, and you may be sure that we will support you from a safe distance, and thank you afterwards, and that we will not hold you accountable."

Although a government commission in 2012 engaged in fact finding and wrote a report, the government did not follow up with the institution of truth and reconciliation processes. As Oppenheimer's films demonstrate, the dominant narrative is still substantially supported by the government. However, the narrative is not intractable. In groundbreaking developments in April 2016, President Widodo instituted National Symposium on the 1965 Tragedy which took place in Jakarta (Melvin). The symposium may prove to be a first step toward a truth and reconciliation process. The strength of 
counter-narratives, tentative government initiatives, and the progress of unofficial processes, indicate readiness and a path forward if the government elects to invest its power, resources, and prestige in designing and implementing a process to transform the conflict. Dialogue, memory and memorialization, apology and forgiveness, and reconciliation are evolving informally on a small scale, primarily, but not exclusively, in non-governmental arenas.

\section{b. Dialogue}

Adi goes to the homes of the killers to talk to them. He realizes they will not initiate this discussion. He sees the path to revising the narrative as reliant on interaction and communication. He positions himself as a humble and gentle person. He does not demand that the killers admit to murdering his brother, offer him any form of compensation, or leave town. Adi is not looking for revenge, but for ways to talk with people in his own community who are deeply divided from one another based on which side of the conflict they are on. This strategy is well-aligned with the process of dialogue as a tool of conflict transformation. Dialogue transforms the way people in deeply divided societies relate to each other (Maddison 225) by creating opportunities for opposing parties to begin to learn how to understand one another differently and to imagine new relational possibilities by speaking openly with one another (225).

Unfortunately, however, dialogue is not as simple as bringing victims and perpetrators together to talk about the past and the ongoing conflict between them. Constructive dialogue can only reach the goal of humanizing historical conflicts (Maddison 216) if it is facilitated by government agencies. Further, dialogue must lead to the implementation of concrete action, such as public policy revisions (Noriega, as qtd. in 
Maddison 267). This process depends on the patience and willingness of individuals, communities, and government agencies to collaborate (269).

The process of initiating dialogue on a large scale about the catastrophe of 1965 in Indonesia is rife with frequent setbacks. Journalists call for official apologies; citizen groups such as the witnesses who testified in the Hague call for the international community to nominate the massacres and predicate them as crimes against humanity; some political bodies make statements about the crimes committed, but then others step in to say that they see no need to address events long past. Worse still is the silence of many political actors and institutions. Many Indonesians have been disappointed by President Widodo, who promised in his election campaigns that he would take action regarding the slaughter of 1965 , but refused early in his administration to issue an official apology to the victims (Pamuntjak). However, President Widodo recently took decisive action by following up the first-ever governmentally-instituted symposium on the events of 1965 with the authorization of a formal inquiry (Melvin). These steps may lead to dialogue structured by the government, which would maximize the possibility of a beneficial outcome.

At this point, non-governmental bodies have been active in trying to initiate dialogue. Indeed, it seems like the starting place for dialogue so far is at the level of individuals like Adi Rukun. Person-to-person interactions may be beneficial, and may open a door to formally-instituted governmental truth and reconciliation processes. In an interview with Dana Stevens of Slate, Oppenheimer quotes Adi as saying that meeting the perpetrators is helpful because it can be a way for killers and victims to recognize their shared humanity. Adi says that he hopes, in approaching the perpetrators as their 
neighbor, "wwith empathy and an attempt to understand,", he may be able to show the killers that the victims were not one-dimensional sadists, but perhaps that they too were gentle people who did not deserve to be massacred (Stevens). This realization may lead perpetrators to recognize wrongdoing, and can be a starting point for apology and forgiveness (Stevens). “'Once they apologize,"” Adi says, “" I'll be able to forgive them, because I'll be able to separate their crime from their humanity. Then we'll be able to live together as human beings and as neighbors instead of perpetrator and victim, afraid of each other"” (Stevens).

Adi's counter-narrative arises from his dialogue with killing squad members and is contextualized in rhetorics of morality, "moral responsibility," honesty, accountability, and forgiveness (Silence). Every experience Adi has with the killers involves their distancing themselves — "trying to wash [their] hands"- from any sort of responsibility (Silence). So, perplexingly, while perpetrators will happily recount their actions killing, beating, and interrogating suspected communists, none of them is willing to accept any amount of moral responsibility to their community for executing innocent people. Adi utilizes dialogue as a way of "opening" and revising a "distorted" history (Silence). By opening history up for discussion, Adi believes that the community can come together to make sense of it differently, in a way that recognizes the experiences of the marginalized population. The strides Adi makes to initiate dialogue are courageous, yet they ultimately fall short because they lack institutional support. Amir Siahaan, M.Y. Basrun, and one of Amir Hasan's sons all threaten Adi when he appears to be overstepping the boundaries set by the dominant narrative, revealing their vulnerability to being re-predicated as criminals (instead of as heroes) in a new narrative. 
There are certain limits to what is attainable when dialogue is concentrated at the level of individual interactions. Government agencies need to be involved. It is unacceptable that attempts at revising the meaning of the commonly agreed upon facts, such as in the report issued by the National Commission on Human Rights (Komnas HAM)—which deemed 1965 as a gross human rights violation — have been rejected by some ministers and governmental agencies (Aritonang, “1965 Mass Killings”). The fact that interactions such as those between Adi and the killers in his community are taking place, the publication of books such as Laksmi Pamuntjak's Amba and Leila S. Chudori's Pulang, which address the trauma of 1965 (Kwok, "Movie, Books"), as well as articles and journalism calling for state action, are strong indications of readiness for dialogues to take place on a larger scale. As discussed, recent actions by President Widodo may also be indicative of readiness among Indonesia's political elites (Melvin).

\section{c. Memory and Memorialization}

Challenging ahistorical national narratives of state-sanctioned violence and creating new narratives, new tellings of history, is the first step to creating a shared vision for how a society will deal with the aftermath of traumatic violence. At the root of changing dominant, non-factual narratives is coming to a sense of agreement on how the events will be remembered. This may require "revising pre-existing narratives" and earlier experiences (Opotow 161). Establishing a shared narrative relies on constructive dialogue, in which victims and perpetrators have space to articulate their experiences. This is a "prerequisite for achieving accountability, meaningful reconciliation, and a foundation for a common future" (Chapman, as qtd. in Maddison 49). 
A significant step that Indonesia's government has taken to this end is the Komnas HAM report. Over four years of research went into compiling a report that ultimately deemed the events of 1965 as "state-sponsored gross human rights violation[s]" (Aritonang, "National Commision"). This promising conclusion was disappointingly rejected by the Coordinating Political, Legal, and Security Affairs Minister Djoko Suyanto, who responded that "the mass killings were justified to save the country from communism. The Attorney General said that the evidence [provided in the report] was insufficient to justify a legal probe" (Kwok, "Movie, Books"). Suyanto also stated that the country "would not be what it is today if [the killings] didn't happen" (Aritonang, "1965 Mass Killings"). It is clear that resistance to opening up about the crimes does come at a cost for state actors and institutions that are implicated in them. Understandably, they do not want to advance reports that counter their claims to rightful authority. The wariness, defensiveness, and territoriality of government actors are part of the ongoing manifestation of the untransformed conflict and are impediments to a truth and reconciliation process in Indonesia. They are indicative of a continuing lack of will and readiness on the part of many government actors to create and implement such a project.

The amazing thing about Indonesia is that if President Widodo's fledgling efforts blossom into an authentic truth and reconciliation process, the "truth" processes (dialogue, memory retrieval, and memorialization) will be relatively easy to implement. Memory retrieval is not a problem where the killers have enjoyed impunity. Since the killers don't deny the facts, establishing a shared account of what happened, who was involved, and when will be relatively simple. The question will be how the facts should 
be interpreted. The government still largely supports and protects proponents of the narrative that the killings were part of a nation-building process; that the dead were casualties of the creation of a democratic Indonesia. But there are also people articulating a more nuanced version of the official story. Anwar has his doubts about the rightness of what he did, for example. Although it is not clear if Anwar has taken any action resulting from his experiences making The Act of Killing, Oppenheimer's personal generosity and openness to the killers is an approach that could provide a framework for embracing a meaning for the facts that does not necessarily insist on revenge, punishment, or stigmatization of the families of the killers.

The extent to which efforts have been made toward the public memorialization of the crimes of 1965 still privileges the dominant narrative. A museum commemorating the deaths of the generals has been built at Lubang Buaya, the site where their bodies were discovered (McGregor). The Sacred Pancasila Monument additionally reconstructs the narrative of the failed coup as a communist plot threatening the national ideology. Commemorations for the massacre victims have yet to be undertaken, as the narrative to which these efforts would correspond is still contested. The memorialization of the successor narrative will entail dismantling some of these earlier memorialization efforts. The shrine for the murdered generals does not need to be torn down, but the museum will have to be rethought to curate exhibits telling an unsanitized story of government engineering of mass executions with the complicity of various civil society actors. When the government is ready to move forward, victim-centered memorialization suited to Indonesia's situation, in which a vast number of paramilitary actors were complicit with the army, could be designed. Dates and sites of mass murders are known. National days 
of remembrance could be declared in honor of the victims. Memorials of some kind, like the stupas in Cambodia, could be erected at the sites of massacres. Gallery space could be used for local artists to make and exhibit their own kind of response to the trauma. Statues or monuments could be constructed in areas hardest hit by the violence. Local artists could be commissioned to paint murals. These are steps like those undertaken in countries around the world to create memorials that have a public presence and manifest the adoption of a new narrative. Such memorials impact how people engage with and remember the violence of their past. Large-scale projects requiring collaboration could be particularly conducive to healing.

\section{d. Apology and Forgiveness}

Apologies are not just an act, but also a process "focused on the possibility of a future relationship" (Verdeja, as qtd. in Maddison 226). Apology is meaningless if it is not followed by decisive action. The Indonesian government has not facilitated projects that draw victims and perpetrators together to build relationships forged through “apology, forgiveness and individual and societal healing” (Maddison 225). But, as can be seen in Oppenheimer's films, nongovernmental processes provide an insight into how ready people are to begin initiating processes of forgiveness, as well as of what form apology and forgiveness processes might take. Forgiveness cannot be extracted from survivors by pressure, but Adi's willingness to go down this path may be an indication that other victims are as well.

Apologies such as those offered by Samsir's daughter and Amir Hasan's wife are valuable in that they seem to arise from a genuine feelings of remorse in response to the facts of their beloved family members' complicity in mass killings. Unfortunately, these 
apologies are also highly superficial and insufficient as a way of recognizing fault and offering condolences. Amir Hasan's wife, especially, offers her apology to Adi in a moment of extreme tension. Her sons have just begun to threaten Adi and Oppenheimer. She has already left the room crying during the interview because they don't listen to her insistence (despite incontrovertible evidence to the contrary) that she never knew about her husband's involvement in the murders. She apologizes not because she truly feels sorry about lying, or about her husband's actions, but because she is trying to placate a hostile situation. Her apology carries little weight, not enough to constitute meaningful reparation. Samsir's daughter's apology is a little more noteworthy, but both of these apologies occur in the realm of person-to-person healing which, while valuable, does little to change the larger situation.

A strong inclination to leave the past in the past, to avoid reopening old wounds; a willingness to admit that wrongs occurred, while insisting that there's nothing to be done about it now; a fear that seriously challenging the official narrative might lead to a renewal of violence — all are impediments to apology. Interestingly, while actual killing squad members are generally hostile to the idea of apology, their family members articulate mitigated versions of the national narrative which are less averse to apology. On the whole, victims are interested in receiving apologies, as long as procuring them does not lead to renewed victimization. At least some of them, such as Adi, would likely answer even a marginally adequate apology with forgiveness.

There is an interesting moment in The Act of Killing when Adi Zulkadry approaches the topic of apology and forgiveness with Anwar. The two are fishing together, and Adi remarks that if he were the child of a communist killed in 1965-66, who 
had, as a result, lived a difficult life (due to the effects of deeply entrenched institutionalized impunity and structural violence—limiting survivors' access to education, employment, legal services and protections, etc.), it would make sense for him to be angry at the men who killed his father. "This needs to be changed," Adi says (this being the disenfranchisement of children and family members of murdered communists). "There's been no official apology—but what's so hard about apologizing? The government would apologize, not us. It would be like medicine. It would reduce the pain" (Killing). Adi Zulkadry's profound mitigation of the rightness claims of the national narrative is thrilling because it is the only direct recognition voiced by any of the killers that the retaliation they so fear from the children of their victims would be justified. Adi perspectivizes himself remotely in his discourse about apology and reconciliation. He is rightly conceiving of government action as the only real solution to a government problem. Yet troublingly, Adi removes himself (and all other killers) from the process. Adi is right in assuming that his actions alone would not be sufficient to start processes of healing and forgiveness, but he falls short of realizing the integral role he would need to play for these apologies to truly "reduce the pain." An official government apology must be accompanied by the perpetrators' direct involvement for meaningful conflict transformation, dialogue, apology, and reconciliation processes to take place. Some indications of readiness to walk that path are shown by Anwar Congo, Amir Hasan's wife, and Samsir's daughter. Apology is a process and need not be perfect in order to support the politicization of the conflict. Conflict caused by the government and self-servingly narrativized by the government is transformed when the government 
intervenes to substitute a more correct narrative and to bring the conflict into the political sphere.

Various actors in the Indonesian government have attempted to initiate measures addressing the conflict since the end of Suharto's reign. President Bacharuddin Habibie, for example, released all remaining political prisoners and ended the tradition of showing the propaganda film on September 30th each year (McGregor). Habibie also promised "revisions to school history textbooks that had previously encouraged hatred towards all alleged communists" (McGregor). President Abdurrahman Wahid suggested lifting the ban on communism and proposed judicial investigations into the killings of 1965-66 (McGregor). His suggestions were met with mass protests from Islamic groups across the country (McGregor). In 2004, "the push for a Truth and Reconciliation Commission [...] encompassing the 1965-66 killings gained momentum," but in 2006 the project was abandoned (McGregor). These efforts, as well as the commissioning of the Komnas HAM report, illustrate the government's capability to institute the necessary processes for truth and reconciliation to begin to take place. Whether recent development in this direction will bear fruit remains to be seen, but the importance of the National Symposium on the 1965 Tragedy and the institution of an inquiry cannot be overstated (Melvin).

Greater vision and leadership is needed to conceive of a process to bring former enemies "into relationships with one another through apology, forgiveness and individual and societal healing" (Maddison 225). An apology by the government to the victims and their surviving family members would serve to open 'political space' in which 'citizens may reflect on more critical views of their troubled histories"' (226). Elite apologies are 
an important first step to instilling greater political stability (226). The power and efficaciousness of official apologies will depend in part on the willingness of men like Anwar Congo to personally apologize and seek forgiveness.

\section{e. Reconciliation}

"Recovering systematically repressed facts about the violent insult to the community, followed by apology and forgiveness to the extent those are achievable, opens a door to reconciliation" (Hamber and Kelly, as qtd. in Maddison 49-50). Hamber and Kelly detail five elements that they see contained in reconciliation: "the development of a shared vision of an interdependent and fair society; a means of acknowledging and dealing with the past; the building of positive relationships; significant cultural and attitudinal change; and substantial social, economic, and political change" (49-50). Finding new ways to bring people together over barriers of "suspicion, prejudice and inequality" (Villa-Vicencio as qtd. in Maddison 46) that are deeply historically entrenched brings about reconciliation as an ongoing process.

The perpetrators of the killings in Indonesia may not ever distance themselves from the rightness of their crimes. Fifty years of impunity, and of having their crimes justified and their rightness claims argumentatively upheld not only by their own communities and government, but by the international community as well, may have irreversibly impacted the way the killers predicate themselves and their actions. As seen in both of Oppenheimer's films, perpetrators have no hesitation when it comes to aligning themselves with what happened. They might feel conflicted about it, but on the whole they all seem perfectly willing to recount the details of the past. 
The promise for conflict transformation may instead lie with the children and grandchildren of death squad members. Children of killers, such as Amir Hasan's sons or Samsir's daughter, seem to want to try to distance themselves from what happened. They make attempts to mitigate their parents' involvement in the killings ("we had no idea", "he never told us"). They offer apologies to Adi. They do not distance themselves from the predications and rightness claims of the national narrative completely, but they do seem to be trying to create some distance between themselves and the acts of the killings. They talk about moving forward as a society. It is possible that these utterances, often the result of duress, could be stepping stones to successfully challenging the narrative and initiating accountability, apology, forgiveness, and reconciliation over time; in short, to transforming the conflict by bringing it into a sphere in which the fear of a resumption of unconstrained violence is banished. 


\section{Conclusion}

Clearly, the conflict which exploded in murderous rage abetted by government actors in 1965 persists in Indonesia today in ways that are severely injurious and deeply menacing. Truth and reconciliation is the only way forward for Indonesia. The alternative, criminal justice processes, are unsuitable due to the sheer numbers of perpetrators, the diffusion of responsibility, government authorization of killing squad activities, the deaths of many primary architects of the policy of extermination, and the cumulative effects of 50 years of impunity (Androff 1961-62). While any truth and reconciliation process must be managed by the government, non-governmental actors (such as Oppenheimer, Adi, citizens who testified at the People's Tribunal in the Hague) have shown that there is some readiness in the Indonesian community as well as a path suited to the unique circumstances of Indonesia's relationship to the catastrophic events of 1965. Possibly as a result of these non-governmental processes, there are now also signs of readiness among political elites at the highest level of national government, as manifested by the recent Symposium on the 1965 Tragedy.

For conflict to be meaningfully and effectively transformed, processes aimed at doing so must take into consideration how dialogues between victims and perpetrators can take place with the support to lead to direct action. These efforts must also contemplate the difficulty of coming to a consensus about the meaning of the killings as an unjustifiable sacrifice of hundreds of thousands of Indonesian lives. Apologies will need to be coupled with action that in some way alleviates the suffering of family members from the impacts of structural and indirect violence. Collusive relationships must no longer be tolerated. Each of these is an enormous task. Disentangling corruption 
and impunity from the social fabric to make room for a new narrative and new venues for conflict management is a process that requires the sustained effort of generations. One certainty is that such behavior as Djoko Suyanto's rejection of the Komnas HAM findings and Vice President Kalla's wholehearted support of Pemuda Pancasila compound the problem and tend to negate advances produced by movements that seek change. Recent actions taken by President Widodo show the way towards imagining and implementing the necessary processes. Lasting, large-scale changes will never be realized without an increasing commitment on the part of political elites. The call to the international community to take full responsibility for their historical complicity and to condemn these crimes may be one way of facilitating this transition.

Is Indonesia ready for a truth and reconciliation process to help rewrite the narrative of the killings of 1965-66? At the level of the people, the answer seems to be yes. Adi Rukun's example is extraordinary, but not unique. People are speaking out about the injustice through many means, writing and publishing books, attending screenings of Oppenheimer's films, accessing and creating journalism online, even going so far as to take their stories to the Hague. These are huge steps in the process of seeking justice and changing the way the conflict is expressed and remembered. The actions of individuals, and of individuals working together, can have amazing transformative effects. Attention must now focus on the government, which fosters the complicated collusive relationships that allow for uncontested impunity. The effects of 50 years of impunity complicate the elements active in Indonesia's nascent process (dialogue; memory and memorialization; apology and forgiveness; and reconciliation). The government will need to work with 
communities to reshape the cultural imagination of how the conflict is managed, and to adequately redefine the role of violence in Indonesia going forward.

Ciorciari and Ramji-Nogales talk about the importance of neutral, non-political ceremonies and rituals to facilitating healing and new ways of remembering historical violence, noting that these rituals tend to be most effective when they are connected to local cultural customs (215). This brings to mind a Muslim ritual of forgiveness and acceptance that I witnessed while living in Jakarta as a student. After Ramadan, I joined my classmates and teachers at school in the ritual of halal bi-halal. The name comes from the Arabic "to accept" or "to forgive" ("Halal Bihalal"). Every person came face to face with every other person. They bowed and touched hands in a sign of respect, asking through this gesture for apology for any wrongs they may have committed and returning by the same gesture acceptance and forgiveness.

While halal bi-halal is tied specifically to Muslim cultural practices, and thus may be exclusive of Indonesian Christians and Buddhists, it is a culturally relevant ritual that could provide a recognizable starting point at the onset of a truth and reconciliation process in Indonesia. Halal bi-halal reveals a well-known path of truth and reconciliation which is familiar to most Indonesians. There is every reason to expect from them a beautifully conceived and implemented process that will succeed in revising the national narrative, bridging the deep divides in Indonesian society, and transforming the conflict in a way that will resonate with people in a culturally accessible way. 


\section{Appendices}

\section{Appendix A: Wodak and Reisigl's Original Discourse-Historical Approach Outline}

Member of the Subcommittee on Energy and Air Quality,J.Dennis Hastert. This letter shares several topics with text 1 , relating to climate change, environmentalism and the threat of freedom, and is also part of various other discourses, for example the discourse on energy economy. Text 2, thus, is a somewhat hybrid genre, as it adopts features of both the (sub)genre of a written expert interview and the (sub)genre of a written letter which resembles the (sub)genre of parliamentary questions and answers.

On 14 June 2007,Vâclav Klaus published an article in the Financial Times entitled 'Freedom, not climate, is at risk'. This text $(=$ text 3$)$ is again part of both discourse $\mathrm{A}$ and discourse $\mathrm{B}$. It picks up many of the topics of text 2 but, of course, manifests characteristics of another genre - the newspaper commentary. This text elicited many reactions and questions by readers, some of which were published in the newspaper on 21 June 2007, and also answered by Klaus (see www.klaus.cz/klaus2/asp/-default. asp?lang=EN\&CatID=YJrRHRsP).

Our triangulatory approach is based on a concept of 'context' which takes into account four levels:

1. the immediate, language or text-internal co-text and co-discourse

2. the intertextual and interdiscursive relationship between utterances, texts, genres and discourses

3. the extralinguistic social variables and institutional frames of a specific 'context of situation'

4. the broader sociopolitical and historical context, which discursive practices are embedded in and related to.

In our analysis, we orient ourselves to all four dimensions of context in a recursive manner (see also Wodak, 2007, 2008a).

\section{Some tools of analysls and princlples of DHA}

The DHA is three-dimensional: after (1) having identified the specific contents or topics of a specific discourse, (2) discursive strategies are investigated. Then (3), linguistic means (as types) and the specific, context-dependent linguistic realizations (as tokens) are examined.

There are several strategies which deserve special attention when analysing a specific discourse and related texts (see Step 5 below). Heuristically, we orientate ourselves to five questions:

1. How are persons, objects, phenomena/events, processes and actions named and referred to linguistically?

2. What characteristics, qualities and features are attributed to social actors, objects, phenomena/events and processes?

3. What arguments are employed in the discourse in question?

4. From what perspective are these nominations, attributions and arguments expressed?

5. Are the respective utterances articulated overtly; are they intensified or mitigated? 
According to these five questions, we elaborate five types of discursive strategies. By 'strategy', we generally mean a more or less intentional plan of practices (including discursive practices) adopted to achieve a particular social, political, psychological or linguistic goal. Discursive strategies are located at different levels of linguistic organization and complexity. ${ }^{4}$

\section{TABLE 4.1 A selection of discursive strategies}

\begin{tabular}{|c|c|c|}
\hline Strategy & Objectlves & Devices \\
\hline nomination & $\begin{array}{l}\text { discursive construction of } \\
\text { soclal actors, } \\
\text { objects/phenomena/ } \\
\text { events and processes/ } \\
\text { actions }\end{array}$ & $\begin{array}{l}\text { membership categorization devices, } \\
\text { deictics, anthroponyms, etc. } \\
\text { - tropes such as metaphors, metonymies } \\
\text { and synecdoches } \\
\text { (pars pro toto, totum pro parte) } \\
\text { verbs and nouns used to denote } \\
\text { processes and actions, etc. }\end{array}$ \\
\hline predication & $\begin{array}{l}\text { discursive qualification of } \\
\text { social actors, objects, } \\
\text { phenomena, events/ } \\
\text { processes and actions } \\
\text { (more or less positively or } \\
\text { negatively) }\end{array}$ & $\begin{array}{l}\text { - stereotypical, evaluative attributions of } \\
\text { negative or positive traits (e.g. in the } \\
\text { form of adjectives, appositions, } \\
\text { prepositional phrases, relative clauses, } \\
\text { conjunctional clauses, infinitlve clauses } \\
\text { and participial clauses or groups) } \\
\text { - explicit predicates or predicative } \\
\text { nouns/adjectives/pronouns } \\
\text { - collocations } \\
\text { - explicit comparisons, similes, metaphors } \\
\text { and other rhetorical figures (inciuding } \\
\text { metonymies, hyperboles, litotes, } \\
\text { euphemisms). } \\
\text { - allusions, evocations, } \\
\text { presuppositions/implicatures, etc. } \\
\text { - topol (formal or more content-related) }\end{array}$ \\
\hline argumentation & $\begin{array}{l}\text { justification and quest- } \\
\text { ioning of claims of truth } \\
\text { and normative rightness }\end{array}$ & - delctics \\
\hline $\begin{array}{l}\text { perspectivization, } \\
\text { framing or } \\
\text { discourse } \\
\text { representation }\end{array}$ & $\begin{array}{l}\text { positioning speaker's or } \\
\text { writer's point of view and } \\
\text { expressing involvement or } \\
\text { dlstance }\end{array}$ & $\begin{array}{l}\text { - direct, indirect or free indirect speech } \\
\text { - quotation marks, discourse markers/ } \\
\text { particles } \\
\text { - metaphors } \\
\text { - animating prosody, etc. } \\
\text { - diminutives or augmentatives }\end{array}$ \\
\hline $\begin{array}{l}\text { Intensification, } \\
\text { mitigation }\end{array}$ & $\begin{array}{l}\text { modifying (intensifying or } \\
\text { mitigating) the lilocut- } \\
\text { lonary force and thus the } \\
\text { epistemic or deontic } \\
\text { status of utterances }\end{array}$ & $\begin{array}{l}\text { - (modal) particles, tag questions, } \\
\text { subjunctlve, hesitations, vague } \\
\text { expressions, etc. } \\
\text { - hyperboles, litotes } \\
\text { - indirect speech acts (e.g. question } \\
\text { instead of assertion) } \\
\text { - verbs of saying, feeling, thinklng, etc. }\end{array}$ \\
\hline
\end{tabular}




\section{Approaching the analysls of 'dlscourses about cllmate change'}

\section{The DHA In elght steps}

A thorough discourse-historical analysis ideally follows an eight-stage progranme. Typically, the eight steps are implemented recursively:

1. Activation and consultation of preceding theoretical knowledge (i.e. recollection, reading and discussion of previous research).

2. Systematic collection of data and context information (depending on the research question, various discourses and discursive events, social fields as well as actors, semiotic media, genres and texts are focused on).

3. Selection and preparation of data for specific analyses (selection and downsizing of data according to relevant criteria, transcription of tape recordings, etc.).

4. Specification of the research question and formulation of assumptions (on the basis of a literature review and a first skimming of the data).

5. Qualitative pilot analysis (allows testing categories and first assumptions as well as the further specification of assumptions).

6. Detailed case studies (of a whole range of data, primarily qualitative, but in part also quantitative).

7. Formulation of critique (interpretation of results, taking into account the relevant context knowledge and referring to the three dimensions of critique).

8. Application of the detailed analytical results (if possible, the results might be applied or proposed for application).

This ideal-typical list is best realized in a big interdisciplinary project with enough resources of time, personnel and money. Depending on the funding, time and other constraints, smaller studies are, of course, useful and legitimate. Nevertheless, we believe that it makes sense to be aware of the overall research design, and thus to make explicit choices when devising one's own project such as a $\mathrm{PhD}$ thesis. In the latter case, one can certainly conduct only a few case studies and must restrict the range of the data collection (to very few genres). Sometimes, a pilot study can be extended to more comprehensive case studies, and, occasionally, case studies planned at the very beginning must be left for a follow-up project.

Because of space restrictions, we only elaborate on a few of the research stages $(1$, 2,4 and especially 5) in this chapter. We have decided to focus on argumentation analysis in our pilot study, since other strategies such as nomination and predication strategies (which we also take into consideration) are subordinated under the persuasive aims of the text we want to analyse.

\section{Analysing dlscourses on climate change and global warming}

Step 1: Actlvation and consultation of preceding theoretical knowledge The overarching research question on 'global warming' can be approached in various ways: 
Appendix B: Critical Discourse Analysis for The Act of Killing

Table 1: The Act of Killing

\begin{tabular}{|c|c|c|}
\hline Questions & $\begin{array}{l}\text { Discursive } \\
\text { Strategies }\end{array}$ & Purpose \\
\hline $\begin{array}{l}\text { How are persons, objects, } \\
\text { phenomena/events, } \\
\text { processes, and actions } \\
\text { named and referred to } \\
\text { linguistically? }\end{array}$ & $\begin{array}{l}\text { Nomination } \\
\text { Strategies }\end{array}$ & $\begin{array}{l}\text { Discursive Construction of Social Actors, } \\
\text { Objects/Phenomena/Events, Actions: } \\
\text { - Proper names: Anwar Congo, } \\
\text { Herman Koto, Adi Zulkadry, Jusuf } \\
\text { Kalla, Ibrahim Sinik } \\
\text { - Pronoun Use: 'l', 'us', 'we'--group } \\
\text { identity further expressed through } \\
\text { appellations of 'the people' and 'the } \\
\text { nation'--killers were defending the } \\
\text { nation's democracy } \\
\text { - Events were necessary } \\
\text { - Ideological: communism, democracy, } \\
\text { preserving social order }\end{array}$ \\
\hline $\begin{array}{l}\text { What characteristics, } \\
\text { qualities, and features are } \\
\text { attributed to social actors, } \\
\text { objects, phenomena/events, } \\
\text { and processes? }\end{array}$ & $\begin{array}{l}\text { Predication } \\
\text { Strategies }\end{array}$ & $\begin{array}{l}\text { Discursive Characterization/Qualification } \\
\text { of Social Actors, Objects, Phenomena, } \\
\text { Events, Processes, and Actions: } \\
\text { - } \quad \text { Killers: brave, heroic, courageous } \\
\text { national heroes } \\
\text { - Victims/Communists: weak, } \\
\text { suspicious, subversive, unworthy } \\
\text { - Sadistic (applied both to methods } \\
\text { used by killers and to the communists } \\
\text { who killed the } 6 \text { generals-justifying } \\
\text { cruelty by emphasizing cruelty of } \\
\text { others) } \\
\text { - Extraordinary events calling for } \\
\text { extraordinary action } \\
\text { - Salvation of Indonesia's democracy } \\
\text { Praise for free-man spirit of Pemuda } \\
\text { Pancasila } \\
\text { Voices of victims emerge in } \\
\text { reenactments begging, pleading, } \\
\text { weeping-showing their own } \\
\text { perception of their innocence and of } \\
\text { the killers' brutality } \\
\text { Ethnic Chinese actor: predicating his } \\
\text { stepfather as deserving of death, } \\
\text { assassins as powerful and justified } \\
\text { Women and children actors as } \\
\text { innocent victims, begging for mercy }\end{array}$ \\
\hline
\end{tabular}




\begin{tabular}{|c|c|c|}
\hline & & $\begin{array}{l}\text { Oppenheimer: innocent victims, } \\
\text { perpetrators detached from their own } \\
\text { actions } \\
\text { - Victim actors seeming to understand } \\
\text { that they deserved death in final } \\
\text { production number }\end{array}$ \\
\hline $\begin{array}{l}\text { Which arguments are } \\
\text { employed in the discourse in } \\
\text { question? }\end{array}$ & $\begin{array}{l}\text { Argumenta- } \\
\text { tion } \\
\text { Strategies }\end{array}$ & $\begin{array}{l}\text { Arguments supporting truth and } \\
\text { rightness claims of the dominant national } \\
\text { narrative: } \\
\text { - Kalla: heroic citizens doing what } \\
\text { needed to be done when gov't alone } \\
\text { could not act } \\
\text { - Victim actors awarding Anwar with a } \\
\text { medal, thanking him for killing them- } \\
\text { supports killers as national saviors } \\
\text { Arguments countering truth and } \\
\text { rightness claims of the dominant national } \\
\text { narrative: } \\
\text { - Anwar admitting that he has } \\
\text { nightmares about the killings, that he } \\
\text { killed people who did not want to die } \\
\text { Ethnic Chinese actor's emotional } \\
\text { outburst challenging narrative by } \\
\text { predicating killers as ruthless villains, } \\
\text { illuminating his victimization and fear }\end{array}$ \\
\hline $\begin{array}{l}\text { From what perspective are } \\
\text { these nominations, } \\
\text { attributions, and arguments } \\
\text { expressed? }\end{array}$ & $\begin{array}{l}\text { Perspectivi- } \\
\text { zation } \\
\text { Strategies }\end{array}$ & $\begin{array}{l}\text { Involvement: } \\
\text { - Most killers are willing to express } \\
\text { intimate involvement } \\
\text { - Ibrahim Sinik telling the crew that he } \\
\text { smeared names of suspects so that } \\
\text { everyone would hate them } \\
\text { - Ibrahim Sinik saying that he got to } \\
\text { choose who lived and who died } \\
\text { Distance: } \\
\text { - Ethnic Chinese actor: perspectivizes } \\
\text { himself as allied with his communist } \\
\text { stepfather }\end{array}$ \\
\hline
\end{tabular}




\begin{tabular}{|c|c|c|}
\hline $\begin{array}{l}\text { Are the respective utterances } \\
\text { articulated overtly, are they } \\
\text { intensified or mitigated? }\end{array}$ & $\begin{array}{l}\text { Mitigation and } \\
\text { Intensification } \\
\text { Strategies }\end{array}$ & $\begin{array}{l}\text { Mitigation: } \\
\text { - Anwar: admitting to drinking and } \\
\text { taking drugs to cope, admitting that } \\
\text { he has nightmares } \\
\text { - Anwar stopping the interrogation } \\
\text { scene short of breath, wondering if } \\
\text { he just experienced what his victims } \\
\text { felt } \\
\text { Intensification: } \\
\text { - Kalla at a public, open air rally, } \\
\text { praising the ability of gangsters to get } \\
\text { things (i.e., killing civilians) done } \\
\text { - Kalla praising Anwar and others in a } \\
\text { large open venue } \\
\text { Oppenheimer: assuring Anwar his } \\
\text { victims felt worse than he could } \\
\text { possibly imagine }\end{array}$ \\
\hline
\end{tabular}


Appendix C: Critical Discourse Analysis for The Look of Silence

Table 2: The Look of Silence

\begin{tabular}{|c|c|c|}
\hline Questions & $\begin{array}{l}\text { Discursive } \\
\text { Strategies }\end{array}$ & Purpose \\
\hline $\begin{array}{l}\text { How are persons, objects, } \\
\text { phenomena/events, } \\
\text { processes, and actions } \\
\text { named and referred to } \\
\text { linguistically? }\end{array}$ & $\begin{array}{l}\text { Nomination } \\
\text { Strategies }\end{array}$ & 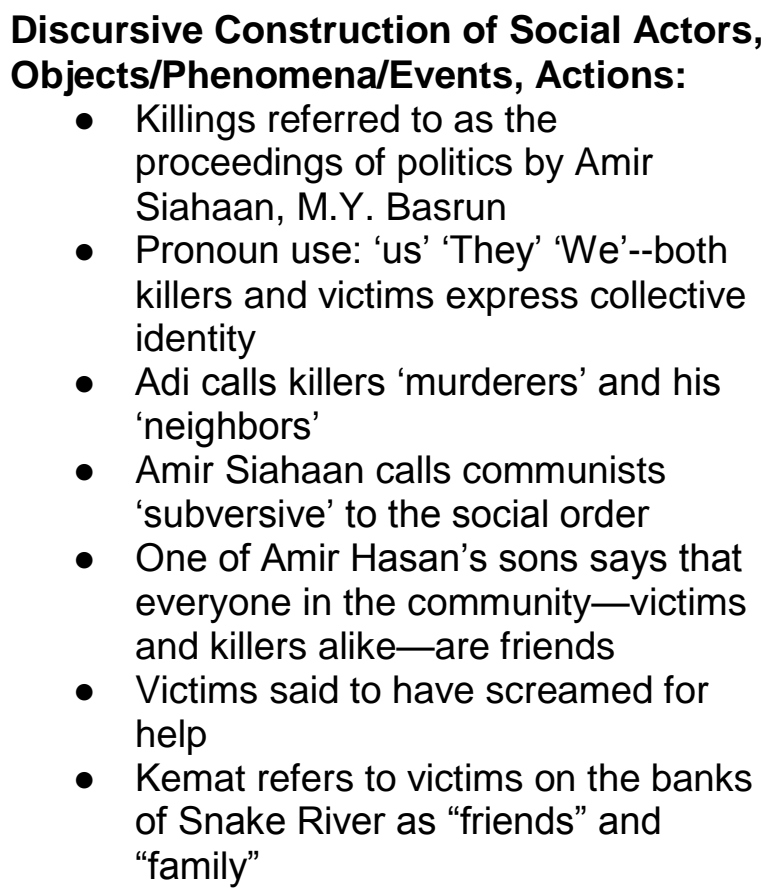 \\
\hline $\begin{array}{l}\text { What characteristics, qualities, } \\
\text { and features are attributed to } \\
\text { social actors, objects, } \\
\text { phenomena/events, and } \\
\text { processes? }\end{array}$ & $\begin{array}{l}\text { Predication } \\
\text { Strategies }\end{array}$ & $\begin{array}{l}\text { Discursive Characterization/Qualification } \\
\text { of Social Actors, Objects, Phenomena, } \\
\text { Events, Processes, and Actions: } \\
\text { - Adi: seeking honesty } \\
\text { - Killers predicate events as just and } \\
\text { correct } \\
\text { - Amir Siahaan: role in death squad } \\
\text { was revolutionary, essential to } \\
\text { formation of democracy } \\
\text { - School Teacher: communists were } \\
\text { ruthless and cruel } \\
\text { - Killers' "heroic struggle" } \\
\text { NBC News Report: families were } \\
\text { liquidated in a purge lasting } 16 \\
\text { months } \\
\text { - Inong and Amir Hasan talking about } \\
\text { the historic killings at Snake River, } \\
\text { communists as enemies } \\
\text { - Samsir's daughter asking Adi to } \\
\text { forgive them, think of them as family } \\
\text { - Killings referred to as a wound both } \\
\text { by Kemat and one of Amir Hasan's } \\
\text { sons }\end{array}$ \\
\hline
\end{tabular}




\begin{tabular}{|c|c|c|}
\hline & & $\begin{array}{l}\text { - Adi: "opening" and revising a } \\
\text { "distorted" history }\end{array}$ \\
\hline $\begin{array}{l}\text { Which arguments are } \\
\text { employed in the discourse in } \\
\text { question? }\end{array}$ & $\begin{array}{l}\text { Argumenta- } \\
\text { tion Strategies }\end{array}$ & $\begin{array}{l}\text { Arguments supporting truth and } \\
\text { rightness claims of the dominant } \\
\text { national narrative: } \\
\text { - Amir Siahaan saying that killers } \\
\text { should be rewarded with a cruise to } \\
\text { America since they played a role in } \\
\text { international politics } \\
\text { - NBC News Report celebrates the } \\
\text { killings-single biggest defeat } \\
\text { handed communism } \\
\text { - NBC News Report: Balinese villager } \\
\text { saying the communists realized they } \\
\text { were wrong and asked to be killed } \\
\text { - Amir Hasan and Inong: agents of } \\
\text { revolution } \\
\text { Arguments countering truth and } \\
\text { rightness claims of the dominant } \\
\text { national narrative: } \\
\text { - Amir Hasan and Inong: saying that } \\
\text { Ramli was 'probably' a good } \\
\text { person-not a one dimensional } \\
\text { villain, but someone who had to be } \\
\text { killed in the context of political } \\
\text { revolution } \\
\text { Families of killers quickly step away } \\
\text { from direct involvement-the Hasan } \\
\text { family all say they've never seen the } \\
\text { book their father wrote before, that } \\
\text { they never knew he was involved } \\
\text { because he never talked about it }\end{array}$ \\
\hline $\begin{array}{l}\text { From what perspective are } \\
\text { these nominations, } \\
\text { attributions, and arguments } \\
\text { expressed? }\end{array}$ & $\begin{array}{l}\text { Perspectivi- } \\
\text { zation } \\
\text { Strategies }\end{array}$ & $\begin{array}{l}\text { Involvement: } \\
\text { - Most killers readily associate } \\
\text { themselves closely to the killings. } \\
\text { They are eager to talk about the } \\
\text { roles they had. They understand that } \\
\text { many people know that they were } \\
\text { involved in the killings to some } \\
\text { extent } \\
\text { - Amir Hasan writing and illustrating a } \\
\text { book to bring the events to life } \\
\text { Distance: } \\
\text { - Samsir's daughter says she never } \\
\text { knew about her father's involvement } \\
\text { in the killings-so do Amir Hasan's } \\
\text { wife and sons } \\
\text { - Hasan family attempt to disengage }\end{array}$ \\
\hline
\end{tabular}




\begin{tabular}{|c|c|c|}
\hline & & $\begin{array}{l}\text { from discussion about their father's } \\
\text { filmed admission of his role as a } \\
\text { killer } \\
\text { Killers back away from direct } \\
\text { involvement when met with the direct } \\
\text { relative of a victim } \\
\text { - Although intimately involved, Kemat } \\
\text { distances himself, says it's not for } \\
\text { him to punish the perpetrators } \\
\text { Rohani distances herself, showing } \\
\text { that the conflict is not really over }\end{array}$ \\
\hline $\begin{array}{l}\text { Are the respective utterances } \\
\text { articulated overtly, are they } \\
\text { intensified or mitigated? }\end{array}$ & $\begin{array}{l}\text { Mitigation and } \\
\text { Intensification } \\
\text { Strategies }\end{array}$ & $\begin{array}{l}\text { Mitigation: } \\
\text { - Amir Hasan and Inong mimicking } \\
\text { Ramli's cries for help before they } \\
\text { killed him } \\
\text { - Samsir and Inong both talk about } \\
\text { drinking blood to keep from going } \\
\text { crazy, that many killers killed so } \\
\text { many they went crazy } \\
\text { Intensification: } \\
\text { - Adi directly challenges killers who } \\
\text { attempt to place responsibility on } \\
\text { someone else, maintains that they } \\
\text { are guilty, that what they did to his } \\
\text { brother and to many others was a } \\
\text { crime } \\
\text { Adi countering the lesson his son } \\
\text { learns in school as a lie }\end{array}$ \\
\hline
\end{tabular}

\section{Works Cited}


Androff, David K. "Truth and Reconciliation Commissions (TRCs): An International Human Rights Intervention and Its Connection to Social Work." British Journal of Social Work 40.6 (2010): 1960-77. Web. 10 Dec. 2015.

Aritonang, Margareth S. “1965 Mass Killings Justified: Minister.” The Jakarta Post, 1 Oct. 2012. Web. 1 Dec. 2015.

---. "National Commission of Human Rights Declares 1965 Purge a Gross Human Rights Violation.” The Jakarta Post, 23 July 2012. Web. 10 Dec. 2015.

Brahm, Eric. "Truth Commissions." Beyond Intractability. ED. Guy Burgess and Heidi Burgess. Conflict Research Consortium, University of Colorado, Boulder, Colorado, USA. June 2004. Web. 1 May 2016.

Ciorciari, John D., and Jaya Ramji-Nogales. "Lessons form the Cambodian Experience with Truth and Reconciliation." Buff. Hum. Rts. L. Rev. 19 (2012): 193.

Cribb, Robert, and Michelle Ford. "The Killings of 1965-66." Inside Indonesia. Inside Indonesia, Jan. 2010. Web. 20 May 2016.

“Halal Bihalal.” Halal Bihalal. Hollit International, 13 Aug. 2015. Web. 01 May 2016.

Kwok, Yenni. "Movie, Books Push Indonesia to Confront Its Bloody Past." Time, 7 Feb. 2013. Web. 10 Dec. 2015.

---. "The Memory of Savage Anticommunist Killings Still Haunts Indonesia, 50 Years On." Time. Time, 30 Sept. 2015. Web. 20 May 2016.

Maddison, Sarah. Conflict Transformation and Reconciliation: Multi-level Challenges in Deeply Divided Societies. New York: Routledge, 2016. Print.

McGregor, Katharine E. “The Indonesian Killings of 1965-1966." Online Encyclopedia of Mass Violence, 4 Aug. 2009. Web. 18 May 2016.

Melvin, Jess. "Symposium on Indonesia's 1965 Genocide Opens Pandora's Box." New Mandala. Australian National University, 9 May 2016. Web. 10 June 2016.

Opotow, Susan. "Reconciliation in Times of Impunity: Challenges for Social Justice." Social Justice Research 14.2 (2001): 149-70. Web. 10 Dec. 2015. 
The Act of Killing. Dir. Joshua Oppenheimer, Christine Cynn, Anonymous. Final Cut for Real, 2012. Netflix.

The Look of Silence. Dir. Joshua Oppenheimer. Final Cut for Real, Anonymous, 2014. Netflix.

Pamuntjak, Laksmi. "It is 50 Years Since the Indonesian Massacre of 1965 But We Cannot Look Away." The Guardian. The Guardian, 29 Sept. 2015. Web. 10 Dec. 2015.

Parry, Richard Lloyd. In the Time of Madness: Indonesia on the Edge of Chaos. New York: Grove, 2005. Print.

Reisigl, Martin, and Ruth Wodak. "The Discourse-historical Approach (DHA).” Wodak and Meyer 87-121.

Stevens, Dana. “'It's as Though ... the Nazis Are Still in Power': An Interview With Joshua Oppenheimer." Slate Magazine. Slate Magazine, 17 July 2015. Web. 01 May 2016.

Studzinsky, Silke. "Closing Statement Prosecutor, The Hague 13 November 2015." 1965Tribunal.org. 1965Tribunal.org, 16 Nov. 2015. Web. 20 Jan. 2016.

Wodak, Ruth, and Michael Meyer. "Critical Discourse Analysis: History, Agenda, Theory and Methodology." Wodak and Meyer 1-33.

---. Methods of Critical Discourse Analysis. London: Sage, 2013. Print. 